Check for updates

Cite this: RSC Adv., 2019, 9, 38119

Received 31st July 2019

Accepted 9th October 2019

DOI: 10.1039/c9ra05943a

rsc.li/rsc-advances

\section{Catalytic developments in the epoxidation of vegetable oils and the analysis methods of epoxidized products}

\author{
Phyu Thin Wai, Pingping Jiang, (D) * Yirui Shen, Pingbo Zhang, Qian Gu and Yan Leng
}

Functionalization of vegetable oils (VOs) including edible, non-edible, and waste cooking oil (WCOs) to epoxides (EVOs) is receiving great attention by many researchers from academia and industry because they are renewable, versatile, sustainable, non-toxic, and eco-friendly, and they can partially or totally replace harmful phthalate plasticizers. The epoxidation of VOs on an industrial scale has already been developed by the homogeneous catalytic system using peracids. Due to the drawbacks of this method, other systems including acidic ion exchange resins, polyoxometalates, and enzymes are becoming alternative catalysts for the epoxidation reaction. We have reviewed all these catalytic systems including their benefits and drawbacks, reaction mechanisms, intensification of each system in different ways as well as the physicochemical properties of VOs and EVOs and new findings in recent years. Finally, the current methods including titrimetric methods as well as ATR-FTIR and ${ }^{1} \mathrm{H}$ NMR for determination of conversion, epoxidation, and selectivity of epoxidized vegetable oils (EVOs) are also briefly described.

\section{Introduction}

Although phthalate plasticizers have been used for many decades in poly(vinyl chloride) (PVC) insulation and jacketing of cables, several commonly utilized phthalates have been recognized or suspected to be harmful, of which diethylhexyl phthalate (DEHP)/dioctyl phthalate (DOP) is the most rigorously

Key Laboratory of Synthetic and Biological Colloids, Ministry of Education, School of Chemical and Material Engineering, Jiangnan University, Wuxi 214122, China. E-mail: ppjiang@jiangnan.edu.cn controlled plasticizer (along with DBP and BBP). In March 2015, the European Commission added DEHP/DOP as well as di normal butyl phthalate (DBP), diisobutyl phthalate (DIBP), and butylbenzyl phthalate (BBP) to Annex II of RoHS. Thus, their presence was stipulated to not exceed $0.1 \%$ in electrical and electronic equipment placed on the European Economic Area (EEA) market, with effect from July 22, 2019 (or July 22, 2021, for medical devices, or medical or industrial controls and instruments). After July 2019, DEHP/DOP, DBP, DIBP, or BBP over $0.1 \% \mathrm{w} / \mathrm{w}$ in any homogeneous plastic or rubber will be RoHS

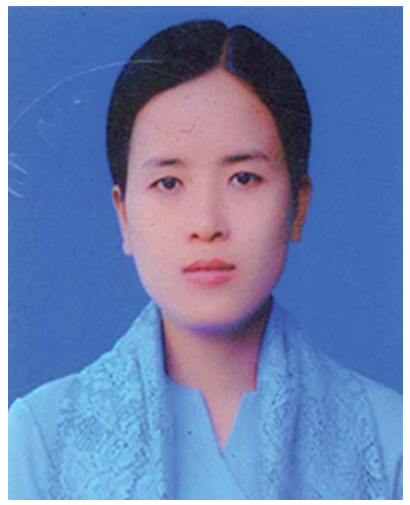

Phyu Thin Wai was born in Taungdwingyi City, Magway Division of Myanmar. She received her Master's degree in 2007 from Yadanabon University, Mandalay Division of Myanmar. Afterwards she joined as an assistant lecturer at the same university in 2009. At present, she is a doctoral candidate at School of Chemical and Material Engineering in Jiangnan University. Her current research area is the catalytic developments in the epoxidation of vegetable oils and their derivatives.

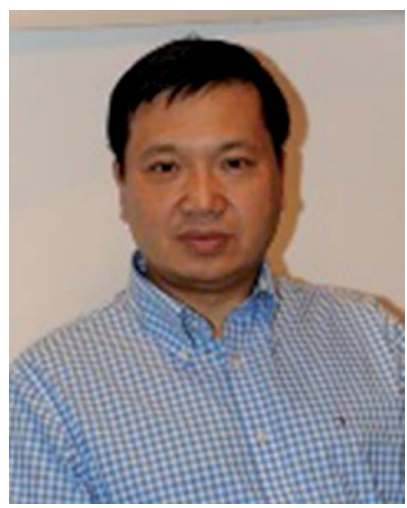

Prof. Dr Pingping Jiang was born in Wuxi City, Jiangsu Province of China. He has obtained a Master's degree from Beijing University of Chemical Technology and doctoral degree from East China University of Science and Technology. He has also been to the University of South Florida, U.S.A. as a senior research scholar. He is now working in the School of Chemical and Material Engineering, Jiangnan University as a doctoral Tutor and academic leader of the research team of Advanced Functional Material and Environmental Additives. He has been engaged in the research of fine organic synthesis and industrial catalytic application. 
non-compliant (2021 for certain types of equipment). ${ }^{1}$ Because of these severe issues, finding an alternative to toxic phthalate plasticizers has become an important concern.

Vegetable oils (VOs) composed predominantly of triglycerides are playing an important role in the chemical industry, thanks to their inherent biodegradability, accessibility, and versatile modifications as well as environmental issues and scarcity of petroleum sources. ${ }^{2}$ According to Statista, vegetable oil production is growing constantly and amounted to some 203.83 million metric tons worldwide in 2018-2019. ${ }^{3}$ Vegetable oils are also extensively utilized as precursors for the production of lubricants, cosmetic products, surfactants, paint formulation, coatings, and resins. ${ }^{4}$ Waste vegetable oils (WVO) as well as non-edible oils such as tall oil, ${ }^{\mathbf{5}}$ jatropha oil, ${ }^{6}$ and cottonseed oil $^{7}$ have become alternative promising candidates of triglycerides that are yet to be profoundly exploited because they have the potential to meet the requirements of low price materials without having the need for competition with food crops. ${ }^{8}$ Besides, the improper disposal of WVO results in oxygen depletion that severely harms aquatic life; technological valorization of WCO can solve such a serious environmental issue. ${ }^{9,10}$ However, appropriate collection management system and analysis of the quality of WCO should be done to meet the requirements for valorization. ${ }^{\mathbf{1 1}}$ It is approximated that the annual production of WVO is over 700000 tonnes in the EU and 4.5 million tonnes in China. ${ }^{12}$ These are attractive sources for making valuable products.

By using proper reagents and catalysts, vegetable oils can be modified into alternative compounds via different reactions, such as epoxidation, hydroxylation, carboxylation, halogenation, hydrogenation, and oxidation. ${ }^{13}$ Among many functionalization reactions of vegetable oils, the epoxidation of vegetable oils is a renowned reaction, with patented applications since 1946 and nowadays, it is becoming more and more popular due to the high reactivity of the epoxy group. ${ }^{14}$

However, the unsaturated sites within the fatty acids of vegetable oils may be less prone to epoxidation in comparison with terminal double bonds of short-chain olefins. ${ }^{15}$ Moreover, it was reported that $\mathrm{H}_{2} \mathrm{O}_{2}$ and oil or fat in the absence of catalysts did not show any apparent reactivity, so an oxidant was crucial to shift the active oxygen from the aqueous to the oil phase. $^{16}$

In addition to $\mathrm{H}_{2} \mathrm{O}_{2}$, organic hydroperoxides (e.g., TBHP) are also appropriate oxidants for epoxidation reactions catalyzed by various transition metal compounds such as $\mathbf{M o}^{\mathbf{1 5}}$ and $\mathrm{Ti}^{{ }^{17}}$ These metals with strong Lewis acid character are active catalysts that act as relatively weak oxidants. In particular, molybdenum-containing complexes have been extensively

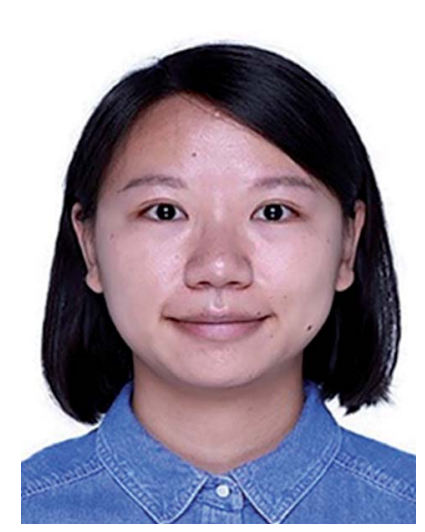

Yirui Shen received her Bachelor's degree from Jiangnan University in China in 2014. Now, she is a doctoral candidate in Jiangnan University. Her research mainly focuses on the design and preparation of heterogeneous catalysts applied in epoxidation of alkenes and vegetable oils.

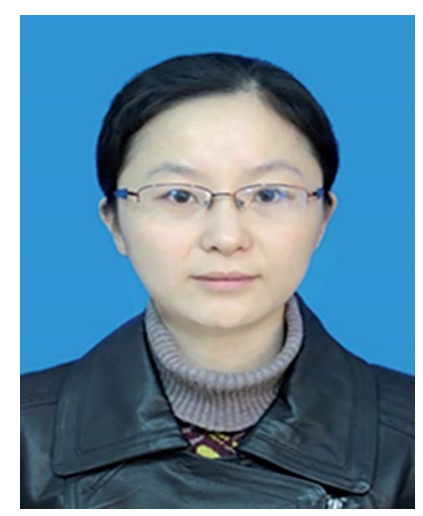

Pingbo Zhang was born in Laizhou City, Shandong Province of China. From the School of Chemical Engineering and Technology, Tianjin University, she received Bachelor's degree in 2004, Master's degree in 2007 and Doctor's degree in 2009. Afterwards, she joined School of Chemical and Material Engineering, Jiangnan University, as Associate Professor. Her present research interests focus on green synthesis and catalytic conversion.

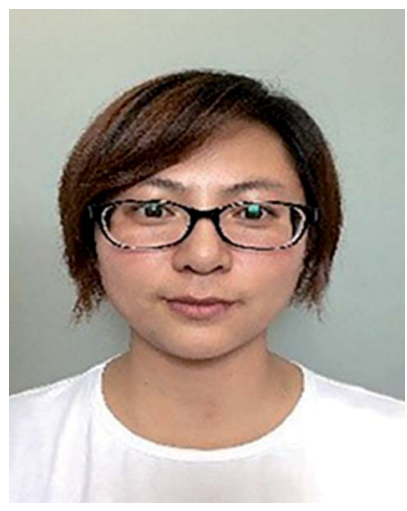

Qian Gu received her Bachelor's degree from Suzhou University of Science and Technology in China in 2013 and obtained her MS degree from Shanghai Institute of Technology in China in 2016. Now, she is a doctoral candidate in Jiangnan University. Her research mainly focuses on heterogeneous catalysis of vegetable oils and its derivatives.

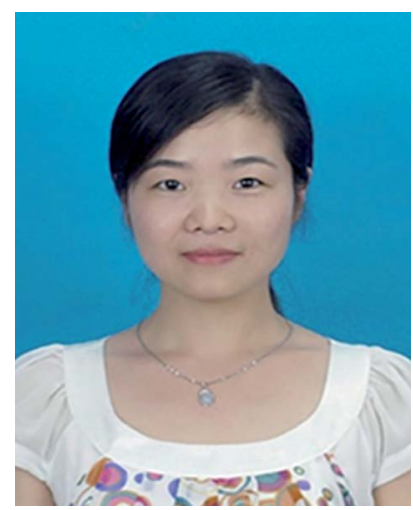

Yan Leng was born in 1983 in Zhengjiang City, Jiangsu Province of China. From the School of Chemical and Material Engineering, Jiangnan University, she received her Bachelor's degree in 2006 and PhD in 2011. Afterwards, she joined the Jiangnan University, as a lecturer. Her present research interests focus on green catalysis and sustainable processes by exploring new catalytic materials composed of ionic liquids, transition metal compounds, heteropolyacids, and porous materials. 
studied due to their good catalytic activity and ready availability. ${ }^{18}$ Vegetable oils including edible, non-edible, and waste cooking oils can be transformed into valuable epoxides by the conventional homogeneous system (current industrial process), in which peracids such as performic acid, peracetic acid, and perpropanoic acid are chosen as oxygen carriers in the presence of $\mathrm{H}_{2} \mathrm{O}_{2}$ and inorganic acid catalysts $\left(\mathrm{H}_{2} \mathrm{SO}_{4}, \mathrm{H}_{3} \mathrm{PO}_{4}\right.$, and $\left.\mathrm{HNO}_{3}\right){ }^{19-26}$ The degradation of oxirane ring as the undesirable side reaction caused by water, hydrogen peroxide, acetic acid, and peracetic acid was studied in detail for the liquid-liquid system. As a result, acid hydrolysis of epoxidized EVOs happens very slowly but degradation of the oxirane ring by $\mathrm{H}_{2} \mathrm{O}_{2}$ in the presence of acid is fast. ${ }^{27}$ It was further found that rate of ring opening caused by peracetic acid and acetic acid is faster than that caused by water and $\mathrm{H}_{2} \mathrm{O}_{2} \cdot{ }^{28}$ The concentration of acetic acid is higher than that of peracetic acid due to the constant regeneration of acetic acid in the epoxidation reaction and consequently carboxylic acids mostly cause degradation of the oxirane ring. ${ }^{29}$ Researchers have focused on other homogeneous systems using methyltrioxorhenium (MTO) $-\mathrm{CH}_{2} \mathrm{Cl}_{2} / \mathrm{H}_{2} \mathrm{O}_{2}$ biphasic system, ${ }^{\mathbf{3 0}}$ bis(acetyl-acetonato)dioxo-molybdenum(vi) $\left[\mathrm{MoO}_{2}(\mathrm{acac})_{2}\right],{ }^{15}$ manganese complex, ${ }^{31}$ and citric acid with $\mathrm{H}_{2} \mathrm{O}_{2}$ for the epoxidation of VOs. ${ }^{32}$

To overcome the drawbacks of the former system, to minimize the unwanted side reactions, and to improve the high epoxy yield, acidic ion exchange resins are becoming the substitutes for inorganic acid catalysts. ${ }^{33-40}$ The reaction mechanisms of epoxidation by inorganic acid and AIERs are the same, in which the catalysts speed up the perhydrolysis (peracid formation) that is the rate determining step of the reaction. ${ }^{\mathbf{4 1}}$ Similarly, phase transfer agents play the part of catalysts for the epoxidation of vegetable oils as a solvent-free system. Tungstenbased catalysts including polyoxometalates (POM) show high epoxide selectivity. POM reacted with $\mathrm{H}_{2} \mathrm{O}_{2}$ to form soluble molecular species (peroxo POM). Using the phase-transfer catalyst, $\mathrm{Q}^{+}\left(\left[\left(\mathrm{C}_{8} \mathrm{H}_{17}\right)_{3} \mathrm{NCH}_{3}\right]_{3}{ }^{+}\right)$, the active oxygen from the peroxo POM is almost fully transferred from the water phase to the oil phase. The reaction takes place preferentially in the organic phase via the active oxygen atom and oxirane group was formed in the organic phase. ${ }^{\mathbf{4 2 - 4 5}}$ Chemoenzymatic epoxidation commonly using Novozyme 435 has become an alternative means for the epoxidation of oils as an environmentally friendly process. $^{6,46-48}$ Other heterogeneous catalysts such as HY zeolite, ${ }^{49} \mathrm{SiO}_{2} @\left(\mathrm{CH}_{2}\right)_{2} \mathrm{COOOH},{ }^{50}$ sulfated-SnO ${ }_{2},{ }^{51} \mathrm{Nb}-\mathrm{SiO}_{2},{ }^{52}$ CoCuAl layered double hydroxides, ${ }^{53}$ commercial alumina, ${ }^{54-56}$ copper supported on alumina with cumene and $\mathrm{O}_{2}$ as the oxidant, ${ }^{57}$ poly(4-vinylpyridine) $\mathrm{CH}_{3} \mathrm{ReO}_{3}$ supported on halloysite nanotubes, ${ }^{58}$ Ti-incorporated mesoporous silica, ${ }^{59}$ and $\mathrm{N}_{2} \mathrm{O}_{5}-\mathrm{SiO}_{2}$ (ref. 60) have been developed recently as alternatives for the epoxidation of VOs. These catalyst systems except HY zeolite and sulfated- $\mathrm{SnO}_{2}$ use only $\mathrm{H}_{2} \mathrm{O}_{2}$ as the oxidant without the need of extra acid for the epoxidation reactions, making them interesting in terms of green and recyclable conditions.

These epoxidized vegetable oils were commonly used as PVC plasticizers (primary ${ }^{61}$ and secondary ${ }^{62-64}$ ) to entirely or partially replace detrimental phthalates, low-temperature lubricants, ${ }^{51}$ and high-temperature lubricants, ${ }^{65}$ stabilizers for PVC and starting materials to produce polyols and prepolymers in surface coating formulations and to synthesize polyurethane foams. ${ }^{66,67}$ Epoxidized vegetable oils are intermediates for the production of isocyanate and non-isocyanate polyurethane. The former can be prepared from the ring opening product of EVOs and harmful isocyanate. The pathway for non-isocyanate polyurethane consists of a series of esterification, epoxidation, carbonation, and aminolysis reactions. Indeed, it is an interesting route due to it being greener and safer. ${ }^{68-70}$ Epoxidized soybean oil (ESO) occupies about $4.9 \%$ of the total plasticizer market. ${ }^{71}$ After epoxidation, some extent of double bonds remains unchanged, which increases the molar mass of the product and consequently, reduces the compatibility with PVC. Besides, the plasticizing efficiency of epoxidized triglyceride oils is inferior compared to DEHP/DOP. These are the reasons why epoxidized triglyceride oils are mostly utilized as secondary plasticizers. ${ }^{72-74}$ Epoxy groups catch the $\mathrm{HCl}$ released from the thermal degradation of PVC, give exceptional light, and heat stability to PVC. $^{75}$

Until now, every catalytic system has been associated with both benefits and bottlenecks. This is why researchers are focused on finding modified new routes such as new catalysts and process intensification (PI). PI is the alternative approach for the advancement of innovative processes and new products, which is currently in demand..$^{76,77}$ For PI, it is needed to know the physiological properties of vegetable oils and their epoxidized products in addition to the benefits and drawbacks of each catalytic system. There are a few works of literature that discuss this. ${ }^{78-80}$ When it comes to process intensification, there are two approaches such as modification of equipment and methods. The equipment class includes the development of intensified reactors such as microreactor or equipment, which in turn can be used for multiple operations. On the other hand, the modification of methods comprises the development of processes by using alternative energy resources or improvement of yield with synergistic effects such as mixing program, ${ }^{22}$ ultrasonic irradiation, ${ }^{47,62}$ microwave technology, ${ }^{81-87}$ high temperature,$^{88}$ and hydrodynamic cavitation. ${ }^{89}$

Our group has studied amphiphilic phosphotungstatepaired ionic copolymer ${ }^{90}$ and molybdenum-based catalysts $^{91-98}$ on various supports for the epoxidation of different alkenes and good results were obtained. Moreover, recent developments in the application of molybdenum-based catalysts for epoxidation have been reviewed as well. ${ }^{99}$ When it comes to vegetable oils, ion exchange resin, ${ }^{\mathbf{1 0 0}}$ chemoenzymatic epoxidation, ${ }^{101}$ and others associated with catalysts for epoxidation and properties of epoxidized vegetable oils ${ }^{66,102,103}$ have been discussed in former review papers. As far as we know, the analytical methods for determination of conversion, selectivity, and epoxide yield have not been reported in the review paper. In our study, we focus on the current methods including conventional methods such as FTIR and ${ }^{1} \mathrm{H}$ NMR techniques that are used for the analysis of epoxidized oil such as iodine value, epoxy value, and $\alpha$-glycol content. Moreover, the technological parameters of different catalytic systems will be highlighted, especially the latest findings and intensification in different ways. 


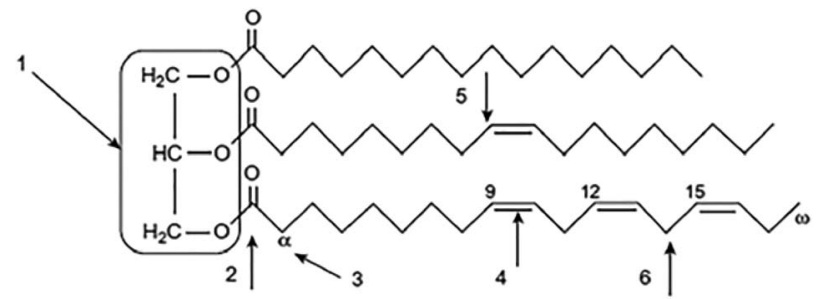

Fig. 1 Typical triglyceride molecule: (1) glycerol linkage, (2) ester group, (3) $\alpha$-position of the ester group, (4) double bonds, (5) monoallelic position, and (6) bisallylic position. Reprinted from ref. 104. Copyright 2000 Wiley-VCH.

\section{The original compositions of vegetable oils and final purposes}

As shown in Fig. 1, triglycerides, which are major components of vegetable oils, contain three fatty acids connected to one glycerol molecule. ${ }^{104}$ Various fatty acids with different carbon chain lengths in the range of 14 to 22 and 0 to 3 double bonds per fatty acid exist in vegetable oils. Among them, two saturated ones, palmitic (C 16:0) and stearic (C $18: 0$ ), and four unsaturated ones, oleic (C 18:1), linoleic (C 18:2), linolenic (C $18: 3)$, and ricinoleic (C $18: 1 \mathrm{OH})$ are the six most common fatty acids. ${ }^{105}$ Fatty acid composition of different vegetable oils and their iodine values are mentioned in Table 1. Two chemical characteristics of VOs capable being of a good plasticizer are a fatty acid chain and the ester groups. While the former can intersperse and intercalate between polymer chains, increase intermolecular spacing, and bring mobility, the latter can interact with polymer chains and bring compatibility. Due to the presence of two reactive sites-the ester groups and the double bonds-chemical modifications can be made via epoxidation to increase compatibility with the polymer. ${ }^{106}$

The overall use of vegetable oils is mainly categorized into two groups: (i) approximately $80 \%$ is exploited in the food industry, and (ii) the rest percentages are shared by other industrial areas. ${ }^{107}$ Generally, various vegetable oils such as soybean oil, linseed oil, palm oil, cottonseed oil, canola oil, corn oil, olive oil, rapeseed oil, and rice bran oil are accessible worldwide at present. ${ }^{108}$ Nowadays, soybean oil and linseed oil have become the most popular for epoxidation since most of the VOs to be epoxidized are not abundant and the price is not outrageous. ${ }^{109}$ According to the Statista portal, in the crop year 2018/2019, some 360 million metric tons of soybeans were produced worldwide. In that year, China was the leading producer of soybean oil worldwide, with the production amounting to 15.77 million metric tons. ${ }^{110}$ Likewise, Hiroaki et al. ${ }^{111}$ stated that 500 million pounds of soybean oil were consumed in industrial applications from 16 billion pounds of the annual production in the United States. Even though soybean oil is still the leading vegetable oil in world consumption, Brink et al. ${ }^{112}$ reported that palm oil has the potential to compare with and exceed soybean oil consumption shortly. However, the low iodine number of palm oil will not be competitive for epoxidation compared to soybean oil. At present, there is an adequate amount of epoxidized vegetable oils available. However, May et al. ${ }^{109}$ and Meyer et al. ${ }^{113}$ approved that vegetable oils with a rather high content of unsaturation or high iodine value such as soybean and linseed oils can be selected as a prior raw material to produce epoxides with high epoxy functionality.

\section{Epoxidation of vegetable oils}

Epoxidation is the chemical reaction that converts the carboncarbon double bond into oxiranes (epoxides) using a variety of oxidizing agents. Various methods have been developed for the epoxidation of vegetable oils as follows:

- Homogeneous catalytic system by peroxyacids.

- Heterogeneous catalytic system by acidic ion exchange resins (AIERs).

- Epoxidation over phosphotungstate heteropolyacid catalysts and in the presence of phase-transfer catalysts $\left(\mathrm{H}^{+} / \mathrm{WO}_{4}{ }^{2-} /\right.$ $\mathrm{PO}_{4}{ }^{3-} / \mathrm{Q}^{+} \mathrm{X}^{-}, \mathrm{QX}$ - onium salt).

- Chemoenzymatic epoxidation.

Table 1 Fatty acid composition of different vegetable oils ${ }^{105}$

Fatty acid composition $(X: Y$, where $X$ is the number of carbon atoms and $Y$ is the number of double bonds), wt $\%$

\begin{tabular}{|c|c|c|c|c|c|c|c|}
\hline Entry & Vegetable oil & Palmitic (C $16: 0)$ & Stearic (C $18: 0)$ & Oleic (C $18: 1)$ & Linoleic (C $18: 2)$ & Linolenic (C $18: 3$ ) & Iodine value \\
\hline 1 & Soybean & 11.0 & 4.0 & 23.4 & 53.3 & 7.8 & $117-143$ \\
\hline 2 & Palm & 42.8 & 4.2 & 40.5 & 10.1 & - & $44-58$ \\
\hline 3 & Rapeseed/canola & 4.1 & 1.8 & 60.9 & 21.0 & 8.8 & $110-126$ \\
\hline 4 & Sunflower & 5.2 & 2.7 & 37.2 & 53.8 & 1.0 & $110-143$ \\
\hline 5 & Groundnut & 11.4 & 2.4 & 48.3 & 31.9 & - & 80-106 \\
\hline 6 & Cottonseed & 21.6 & 2.6 & 18.6 & 54.4 & 0.7 & $90-119$ \\
\hline 7 & Coconut & 9.8 & 3.0 & 6.9 & 2.2 & - & $6-11$ \\
\hline 8 & Palm kernel & 8.8 & 2.4 & 13.6 & 1.1 & - & $14-24$ \\
\hline 9 & Olive & 13.7 & 2.5 & 71.1 & 10.0 & 0.6 & $75-94$ \\
\hline 10 & Corn & 10.9 & 2.0 & 25.4 & 59.6 & 1.2 & $102-130$ \\
\hline 11 & Linseed & 5.5 & 3.5 & 19.1 & 15.3 & 56.6 & $168-204$ \\
\hline 12 & Sesame & 9.0 & 6.0 & 41.0 & 43.0 & 1.0 & $103-116$ \\
\hline 13 & Castor & 1.5 & 0.5 & 5.0 & 4.0 & 0.5 & $82-88$ \\
\hline
\end{tabular}


- Other metal-catalyzed heterogeneous systems with $\mathrm{H}_{2} \mathrm{O}_{2}$, cumene, and $\mathrm{O}_{2}$, TBHP as the oxidant and bio-based catalyst.

- Intensification of the aforementioned processes in different ways.

\subsection{Homogeneous catalytic system}

According to Gerhard and Johannes, the Prileshajevepoxidation process is the initial conventional process used for the industrial production of epoxidized vegetable oils (EVO), in which peroxyacids (peracids) such as peroxyacetic acid or peroxyformic acid have been mostly used as the oxidizing agent. ${ }^{114,115}$ Among peracids, while $m$-chloroperbenzoic acid is highly reactive, costly, and difficult to separate, performic acid is very reactive and corrosive. Peracetic acid is less reactive and corrosive but more selective. The descending order of the reactivity of $m$-chloroperbenzoic, performic, perbenzoic, and peracetic acid is determined by the electron-withdrawing groups of these peracids. ${ }^{116}$ The comparative investigation of the efficiency of different oxidants exhibited that performic acid is more superior to peracetic acid and it is the most suitable oxidant in the range of $40-60{ }^{\circ} \mathrm{C}^{\mathbf{2 0 , 1 1 7}}$ Moreover, performic acid has the potential to undergo decomposition at higher temperature, that is, ca. $60-80{ }^{\circ} \mathrm{C} .{ }^{29}$ Peracetic acid is effective at temperatures above $60{ }^{\circ} \mathrm{C}$. However, increasing temperature will result in higher epoxidation rate as well as a faster rate of product hydrolysis. Cai et al. established that a high concentration of $\mathrm{H}_{2} \mathrm{O}_{2}$ (the hydrogen peroxide to carbon-carbon double bond molar ratio) in the epoxidation reaction causes an increase in the formation of by-products due to the sensitivity of the oxirane ring. ${ }^{118}$ However, at higher temperatures, performic acid is generated due to the high reactivity of formic acid with hydrogen peroxide and the decomposition of a fraction of hydrogen peroxide takes place before participation in the epoxidation reaction. ${ }^{15,117}$

The mechanism of EVO preparation includes three steps together with a parallel decomposition reaction as shown in Scheme 1 (Santacesaria et al., 2011). ${ }^{119}$ Firstly, in the water phase, peroxy-acid is produced reversibly from hydrogen peroxide and the related acid in the presence of a strong mineral acid in situ or in an individual step. Secondly, both organic acid and peroxy-acid are transferred to the organic phase depending on their partition coefficient. Finally, the epoxidation reaction in the organic phase results in the epoxide

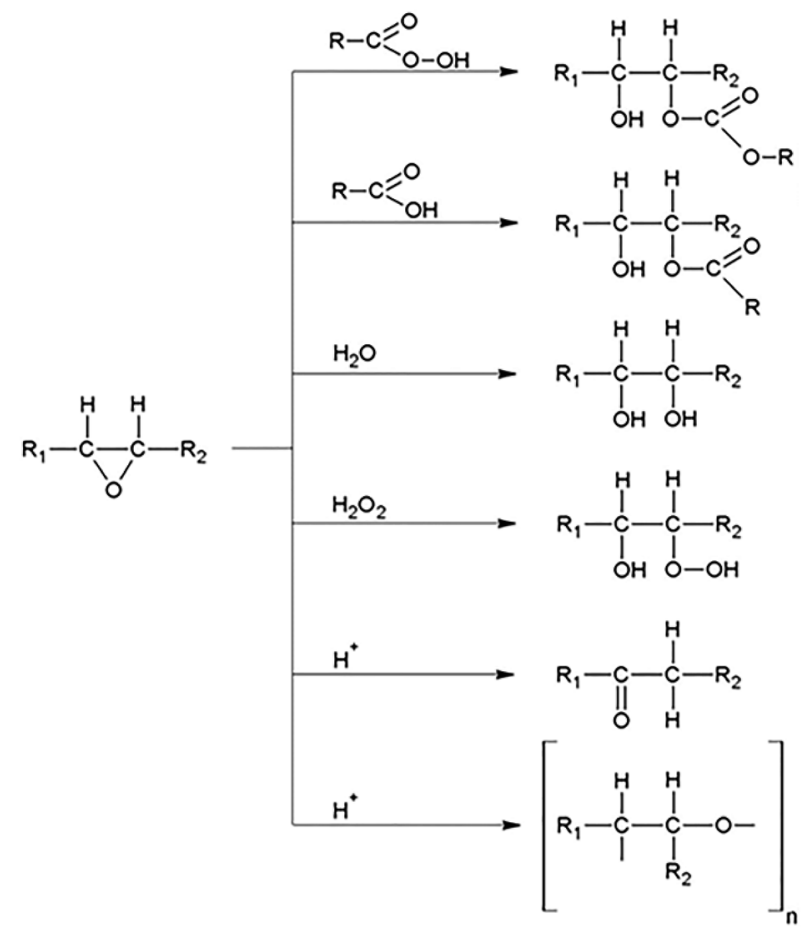

Scheme 2 Side reactions in the conventional epoxidation process.

and the original organic acid. The decomposition of hydrogen peroxide and that of the epoxide product may undergo at the interface as a simultaneous reaction. ${ }^{\mathbf{1 1 4 , 1 1 9 , 1 2 0}}$

The prominent advantages of the classical epoxidation of vegetable oils are a rather high yield of the process, a cheaper price in the peracid synthesis itself (usually acetic acid), the chance of carboxylic acid recapture, as well as its comparative stability under epoxidation parameters. ${ }^{38}$ On the other hand, according to experts, peracid-catalyzed epoxidation suffers from numerous shortcomings. Firstly, as shown in Scheme 2, low selectivity results from the side reactions, such as ring opening of the epoxides that causes the formation of by-products such as diols, hydroxy esters, estolides, and other dimers. ${ }^{16,121-123}$ Secondly, neutralization of the corrosive, strong inorganic acid and aqueous carboxylic acids in the reaction medium yield massive amounts of salt and this gives one surplus obstacle. ${ }^{\mathbf{1 2 1 , 1 2 4}}$ Also, the reaction is highly exothermic $(\Delta H=$ $-55 \mathrm{kcal} \mathrm{mol}^{-1}$ for each carbon-carbon double bond), which<smiles></smiles><smiles>[R]C(=O)OOOC([R])=O</smiles>

Scheme 1 Conventional epoxidation process. Reprinted from ref. 119. Copyright 2011 Elsevier. 
Table 2 Processing parameters for the epoxidation of vegetable oils using homogeneous systems

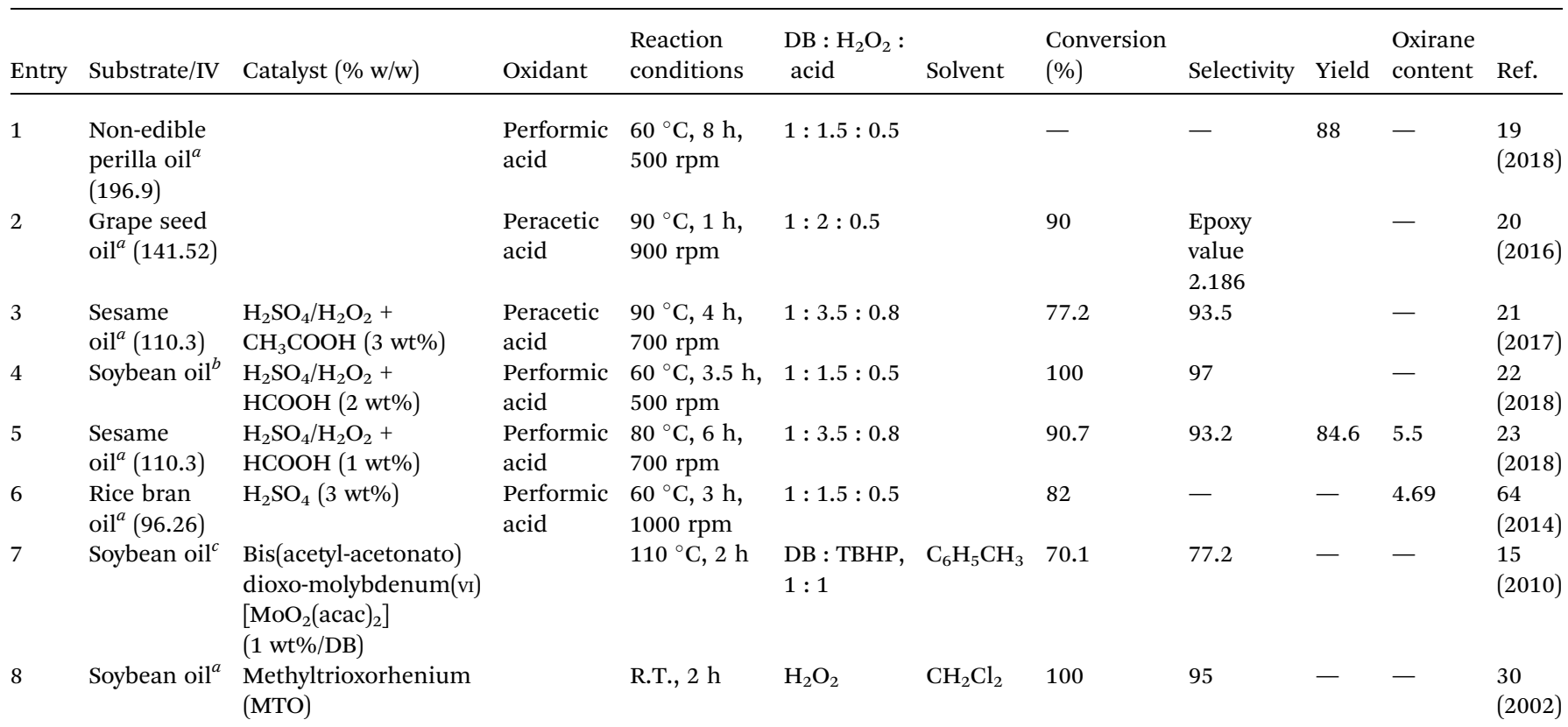

${ }^{a}$ The results are calculated by the titrimetric method as described in the analytical part. ${ }^{b}$ The results are calculated by the FTIR method as described in the analytical part. ${ }^{c}$ The results are calculated by the FTIR method as described in the analytical part.

can cause thermal runaway. ${ }^{\mathbf{1 2 5}}$ Many studies have focused on controlling the reaction under benign conditions and classified the safety parameters required to avoid the runaway reaction in view of kinetic modeling. ${ }^{\mathbf{1 2 6 - 1 3 0}}$

To diminish the side reactions, many types of research have been carried out to search various catalysts and to optimize reaction parameters such as $\mathrm{H}_{2} \mathrm{O}_{2}$ concentrations, acetic acid to ethylenic unsaturation, and solvent systems. In general, an 80\% conversion rate for plant oils can be done with epoxidation in the presence of peracid under boosted conditions ${ }^{131,132}$ while the epoxidation of fatty acid esters gave much higher yield. ${ }^{\mathbf{1 3 3}}$ Milchert et al. ${ }^{100}$ reviewed and concluded from many former observations that the optimum reaction conditions are identical in the epoxidation of oils that possess different iodine numbers (IN $=82-130 \mathrm{~g} / 100 \mathrm{~g}$ ) and different contents of unsaturated fatty acids. However, in many cases, the formation of by-products has yet to be investigated carefully. The processing parameters for the epoxidation of VOs using peracids, methyltrioxorhenium (MTO), and bis(acetyl-acetonato)dioxomolybdenum(vi) $\left[\mathrm{MoO}_{2}(\mathrm{acac})_{2}\right]$ are shown in Table 2.

\subsection{Heterogeneous catalytic system}

To diminish the aforementioned drawbacks of the typical epoxidation reaction, plenty of studies to search for alternative and effective catalytic systems have been carried out until now. Among them, acidic ion exchange resins (AIERs) have become an option. Mungroo et al. ${ }^{\mathbf{1 3 4}}$ described that the epoxidation process of vegetable oils could be done in a cleaner and environmental friendly manner using heterogeneous catalysts, especially AIERs in the place of conventional homogeneous catalysts. AIERs are heterogeneous catalysts capable for the epoxidation of triglycerides, in which active sites are located on a polystyrene matrix crosslinked with divinylbenzene (DVB) content. They are divided into two main categories. The first one is gel-type (microporous) resins with no apparent porosity in the dry state, whose pore sizes are not wide enough to allow the entry of triglycerides into the active sites and are only probable after swelling of the resins in the reaction media. Another one is macroreticular resins with stable macropores in the range of 2 to $200 \mathrm{~nm}$ (ref. 135) including masses of gel-type regions with micropores, released from the swelling of the polymer skeleton. ${ }^{\mathbf{1 3 6}}$ The DuPont de Nemours and Co. Company was a discoverer of new polystyrene sulphonic catalysts that could be effectively functional in the epoxidation of vegetable oil. Although AIERs have a similar efficiency like other strong acids in catalyzing peracid formation, they do not catalyze the ringopening reaction when raw materials have relatively high molecular weight. This is one of the advantages over other strong acids and due to the deficiency of contact of the epoxidized oil with acid centers in the resin. ${ }^{\mathbf{1 3 7}}$ The benefits of AIER catalysts compared to mineral acids include the suppression of unfavorable side reactions, better selectivity, as well as easy separation of the catalysts from the reaction products. ${ }^{39,138}$

The reaction mechanisms of EVO preparation using heterogeneous solid catalyst such as AIERs are similar to the conventional one. In the presence of AIER catalysts, the peracid forms inside the pores and epoxidation of peracid with triglycerides takes place at the outside of the pores in the oil phase. The former includes several sub-steps: (1) diffusion of carboxylic acids and $\mathrm{H}_{2} \mathrm{O}_{2}$ into catalyst pores, (2) adsorption of reactants on the catalyst surface, (3) reaction at the catalyst surface, 


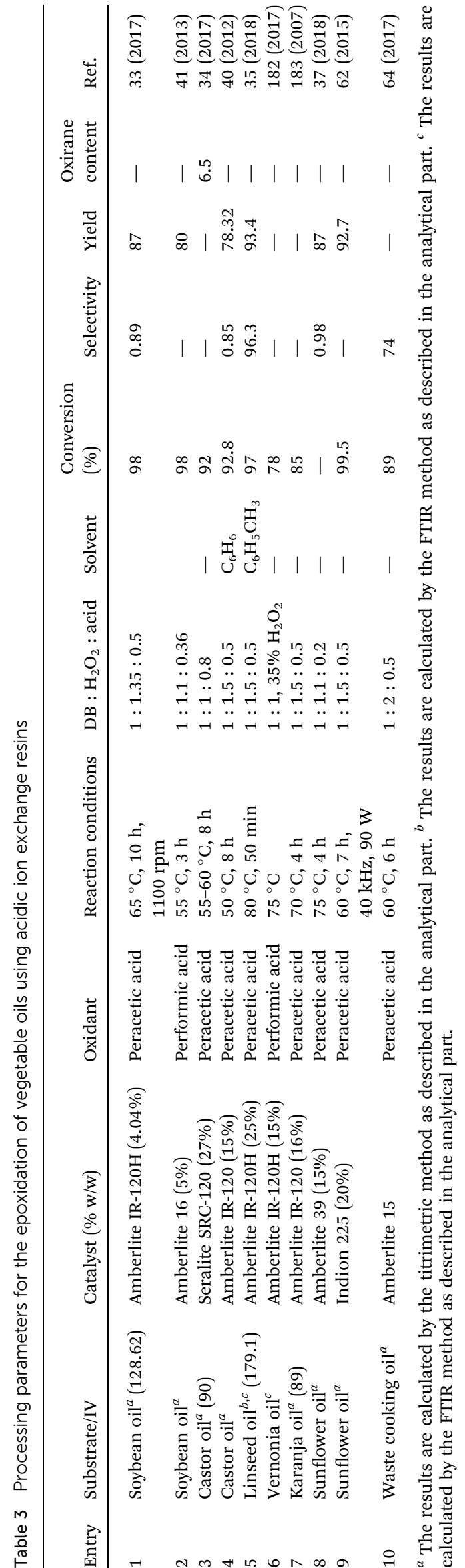

and (4) diffusion of products (peracids) from the catalyst to the bulk reaction mixture. ${ }^{38}$

Researchers have already conducted the epoxidation reactions of VOs with the use of AIERs alone or a comparison of efficiencies of different AIERs with different morphologies and DVB contents. It was observed that, due to high resistance to deterioration of the Amberlyst 39 resin, it could be reused efficiently for up to ten cycles with high oxirane content for the epoxidation of vegetable oils. ${ }^{37}$ Amberlyst 16 has been firstly used for the epoxidation of soybean oil with minimal oxirane cleavage using formic acid and hydrogen peroxide in a semibatch reactor. As a result, $98 \%$ of double bond conversion and more than $80 \%$ of selectivity was achieved with only $5 \%$ of catalyst within a short reaction time $(3 \mathrm{~h})$. Amberlyst 16 is attractive and promising due to its robust mechanical resistance, high conversion, high selectivity (in contrast to the outcomes of Amberlyst 15), and recyclability with no obvious loss of activity. As encountered in Amberlite IR-120, the swelling phenomena and plugging of the reactor did not happen in the case of Amberlyst 16 with macroreticular structure. Moreover, the resin can work in a packed bed continuous reactor. ${ }^{41}$

Jatropha oil was epoxidized with ion exchange resins with different DVB contents such as Dowex 50Wx2 (2\%), Amberlite IR-120 (8\%), Amberlite 15 (20\%), and SAC 13 with acid strength to find the most effective one. The acidity of the former three resins is similar to $45 \% \mathrm{H}_{2} \mathrm{SO}_{4}$ solution and the last one is $85 \%$ of that solution. The results on product distribution show two noteworthy aspects: (a) on one hand, the selectivity towards the epoxides declines due to the formation of more glycols with lower cross-linking from the view of gel-type resins, i.e., $2 \%$ and $8 \%$ DVB; (b) on the other hand, selectivity towards epoxides is still poor due to the formation of glycols because the epoxide ring can open with water by protonating on the high extraparticular surface area of the macroreticular structure. This is from the view of the granular type resin with $20 \%$ DVB, which has the highest cross-linking. The exposure of the epoxide to the acidic sites of the catalyst can be minimized by using resins with low external surface area and high cross-linking. Among the sulfonated ion exchange resins examined in this study, Amberlite IR-120 was the best heterogeneous catalyst for epoxide production (about 90\% conversion and 70\% epoxide selectivity), with stability up to five times. ${ }^{139}$

In the preparation of peroxyvaleric acid, Dowex 50Wx2, Smopex-101, Dowex 50Wx8 $\approx$ Amberlite IR-120, and Amberlyst 15 with the same scale as sulfuric acid at analogous concentration level were chosen and their catalytic activities are in the decreasing order. The effect of external and internal mass transfer limitation was investigated. The experiments also revealed that a gelular resin with a particle size of more than $0.1 \mathrm{~mm}$ and $8 \%$ cross-linking degree (i.e., Amberlite IR-120) showed better resistance to deactivation. ${ }^{140}$ To conclude, the degree of cross-linking plays a major role in the efficiency of the resins because a higher degree of cross-linking makes the reaction rate slower and the lower one can deactivate during the reaction. ${ }^{141}$ Technological parameters such as temperature, catalyst loading, carboxylic acid to double bond ratio, hydrogen peroxide to double bond ratio, and stirring speed are optimized 


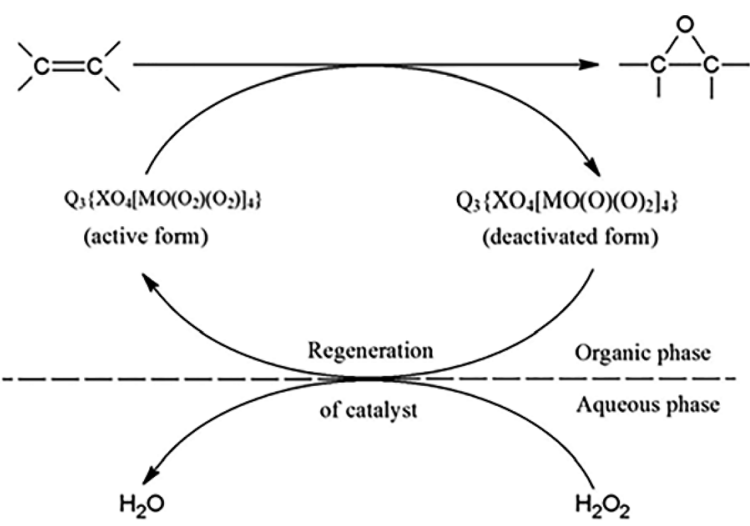

Scheme 3 Epoxidation of unsaturated compounds in the presence of PPOMs. Reprinted from ref. 146. Copyright 2004 Elsevier.

in the epoxidation of VOs with AIERs. The comparison of some literature findings are tabulated in Table 3.

\subsection{The use of polyoxometalates}

Polyoxometalates (POMs) serve as analogs of peracids and are highly efficient catalysts for biphasic epoxidation in an environment friendly manner. ${ }^{142}$ The active intermediates, peroxopolyoxometalates (PPOMs) $\mathrm{Q}_{3}$ (where $\mathrm{Q}=\left[\mathrm{Bu}_{4}{ }^{n} \mathrm{~N}\right]^{+}$, $[\mathrm{MeN}(n$ $\left.\left.\mathrm{C}_{8} \mathrm{H}_{17}\right)_{3}\right]^{+},\left[\pi-\mathrm{C}_{5} \mathrm{H}_{5} \mathrm{~N}\left(\mathrm{CH}_{2}\right)_{15} \mathrm{CH}_{3}\right]^{+} ; \mathrm{X}=\mathrm{P}, \mathrm{As}$, etc.; $\mathrm{M}=\mathrm{Mo}, \mathrm{W}$, etc.) species responsible for epoxidation with hydrogen peroxide, can be obtained by the reaction of POMs with surplus $\mathrm{H}_{2} \mathrm{O}_{2}$ in solution. ${ }^{143}$ Quaternary ammonium salts (QASs) as the phase-transfer agents are necessary to assist the solubility of PPOMs in the organic phase. ${ }^{144}$ Therefore, the reaction encompasses the transfer of peroxopolyanion across the waterorganic interface by phase-transfer catalysis (PTC). The earliest use of PPOMs was in the epoxidation of 1-octene, cyclohexene, 1-dodecene, styrene, and $\alpha$-methylstyrene since $1983 .{ }^{145}$ High selectivity for epoxide (80-90\%) and the noticeably full conversion of hydrogen peroxide are usually accomplished under mild conditions within short times.

The reaction mechanism of the phase-transfer catalysis (PTC) using $\mathrm{H}_{2} \mathrm{O}_{2}$ as the oxidant comprises the in situ formation of peroxoheteropolyanion $\left\{\mathrm{XO}_{4}\left[\mathrm{MO}\left(\mathrm{O}_{2}\right)_{2}\right]_{4}\right\}_{3}{ }^{-}$in the aqueous phase, its stabilization by QAS cations on the interface, and transfer of the active species to the organic phase (vegetable oil). Then, the PPOM reacts with the substrate in the organic phase and the deactivated catalyst regenerates with hydrogen peroxide in the aqueous phase to be active again (Scheme 3). ${ }^{\mathbf{1 4 6}}$

The combined effect of PPOMs and QAS is very useful for the effective epoxidation of vegetable oils either in the homogeneous or heterogeneous form with a suitable support. In the literature, the PPOM catalyst structure is usually used for the selective epoxidation of vegetable oils and their derivatives. ${ }^{42,147}$ It was found that the epoxidation of soybean oil provides an epoxide yield of more than $90 \%$ during $3-4 \mathrm{~h}$ at $60{ }^{\circ} \mathrm{C}$ under mild conditions. ${ }^{147}$ However, it was investigated that the active sites of the catalysts are lost in the course of the reaction and, consequently, deactivation of the catalysts, decrease in activity and selectivity occur. ${ }^{42}$ Moreover, the stability, separation after reaction, and reusability of the PPOMs in the homogeneous form limit their widespread use in the epoxidation of vegetable oils with $\mathrm{H}_{2} \mathrm{O}_{2}$ as the oxidant. To solve this issue, the entrapment of these complexes was carried out on the surface of the polymer support or inorganic solid support. ${ }^{44,45}$ The investigations for the catalytic activity of these catalysts for the epoxidation of vegetable oils are still less and some of the findings for this system are shown in Table 4.

\subsection{Enzymatic method}

Björkling and co-workers ${ }^{148}$ firstly used lipases as the biocatalyst for Prileshajev epoxidation in 1990 (Scheme 4) wherein the carboxylic acid or ester is oxidized to the peracid that is efficient for alkene epoxidation. Likewise, the reaction mechanism of vegetable oils with lipases is similar to that of short chain alkenes. Initially, unsaturated percarboxylic acid is obtained

Table 4 Processing parameters for THE epoxidation of vegetable oils using polyoxometalates

\begin{tabular}{|c|c|c|c|c|c|c|c|c|c|c|}
\hline Entry & Substrate/IV & Catalyst $(\% \mathrm{w} / \mathrm{w})$ & $\begin{array}{l}\text { Reaction } \\
\text { conditions }\end{array}$ & DB : $\mathrm{H}_{2} \mathrm{O}_{2}$ & $\begin{array}{l}\text { Conversion } \\
(\%)\end{array}$ & Selectivity & $\begin{array}{l}\text { Epoxy } \\
\text { yield }\end{array}$ & $\begin{array}{l}\text { Oxirane } \\
\text { oxygen }\end{array}$ & Reuse & Ref. \\
\hline 1 & Soybean oil ${ }^{a}$ & $\begin{array}{l}\text { Peroxopolyoxometalate }\left[\mathrm{PW}_{4} \mathrm{O}_{24}\right]^{3-} \\
\text { with dicationic long-chain } \\
\text { alkyl imidazolium ionic liquids }\end{array}$ & $80^{\circ} \mathrm{C}, 2 \mathrm{~h}$ & $1: 1.5$ & 97 & - & 82.4 & - & 3 & $42(2014)$ \\
\hline 2 & Soybean oil ${ }^{a}$ & $\begin{array}{l}{\left[\mathrm{MeN}\left(n-\mathrm{C}_{8} \mathrm{H}_{17}\right)_{3}\right]\left[\mathrm{PO}_{4}\left[\mathrm{WO}\left(\mathrm{O}_{2}\right)\right]_{4}\right]} \\
\text { supported on modified } \\
\text { halloysite nanotubes }\end{array}$ & $40{ }^{\circ} \mathrm{C}, 2 \mathrm{~h}$ & $1: 3$ & 22.8 & - & 12.27 & - & 3 & $44(2012)$ \\
\hline 3 & Soybean oil ${ }^{a}$ & $\begin{array}{l}{\left[\mathrm{MeN}\left(n-\mathrm{C}_{8} \mathrm{H}_{17}\right)_{3}\right]} \\
\text { supported on palygorskite }\end{array}$ & $40^{\circ} \mathrm{C}, 2 \mathrm{~h}$ & $1: 1.25$ & 65.38 & 58.35 & 38.15 & - & 3 & $45(2014)$ \\
\hline 4 & Soybean oil ${ }^{a}$ & $\begin{array}{l}{\left[\mathrm{MeN}\left(n-\mathrm{C}_{8} \mathrm{H}_{17}\right)_{3}\right]\left\{\mathrm{PO}_{4}\left[\mathrm{WO}\left(\mathrm{O}_{2}\right)\right]_{4}\right\}} \\
\text { supported on palygorskite }\end{array}$ & $\begin{array}{l}50{ }^{\circ} \mathrm{C}, 2 \mathrm{~h} \text {, } \\
\text { ultrasonic }\end{array}$ & $1: 1.5$ & 90.69 & 87.48 & 79.34 & - & 3 & $45(2014)$ \\
\hline 5 & Cardonal oil $^{a}$ & $\left(\mathrm{C}_{17} \mathrm{H}_{30} \mathrm{ClN}\right)_{30} \mathrm{O}_{40} \mathrm{PW}_{12} \cdot x \mathrm{H}_{2} \mathrm{O}$ & $50{ }^{\circ} \mathrm{C}, 3 \mathrm{~h}$ & $1: 1.8$ & - & - & - & 5.2 & 5 & 43 (2019) \\
\hline 6 & Soybean oil ${ }^{a}$ & {$\left[p-\mathrm{C}_{6} \mathrm{H}_{5} \mathrm{~N}\left(\mathrm{CH}_{2}\right)_{15} \mathrm{CH}_{3}\right]_{3}\left[\mathrm{PW}_{4} \mathrm{O}_{16}\right]$} & $\begin{array}{l}60^{\circ} \mathrm{C}, 3-4 \mathrm{~h}, \\
\text { dichloroethane }\end{array}$ & $\begin{array}{l}1: 10 \\
(\mathrm{w} / \mathrm{w})\end{array}$ & - & - & 90 & - & - & $147(2015)$ \\
\hline
\end{tabular}

${ }^{a}$ The results are calculated by the titrimetric method as described in the analytical part. 


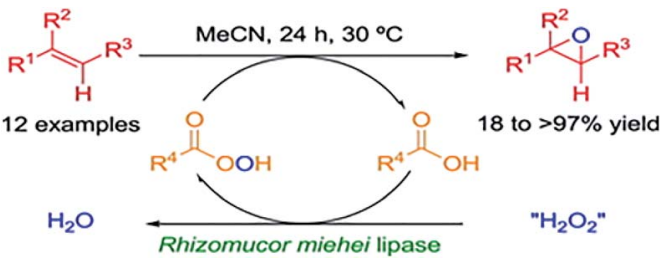

Scheme 4 Chemoenzymatic epoxidation of an alkene.

from the unsaturated fatty acid or ester by a lipase-catalyzed perhydrolysis in the presence of $\mathrm{H}_{2} \mathrm{O}_{2}$ and is then selfepoxidized in an essentially intermolecular reaction as shown in Scheme 5. ${ }^{149,150}$ Perhydrolysis of oils undergoes not only the formation of peroxy fatty acids but also mono- and diglycerides. Although lipase can hydrolyze fatty acids from triglycerides, the addition of FFA is still necessary to control the hydrolysis of fatty acids and eliminate the production of di- and monoglycerides, which are hardly possible to eliminate from the final product and decrease the end product quality. However, when perhydrolysis occurs, the hydroxyl groups of glycerol, monoand diglycerides are esterified again with excess of free fatty acids. This is why the amount of free fatty acids should be adjusted so as to not be in excess. In this way, the reaction product contains only epoxidized triglycerides and epoxidized free fatty acids. Alkaline washing can easily remove free fatty acids. ${ }^{150,151}$

Meanwhile, enzyme-catalyzed epoxidation of vegetable oils yields a rather high epoxy oxygen content (EOC) in the presence of an active oxygen carrier such as long chain fatty acids (mainly stearic acid). However, the acid value (AV) of the final product using stearic acid is high and the removal of free fatty acid with water in the post-treatment is not easy due to limited solubility. Similarly, the removal of free fatty acids with alkali treatment is not desirable due to the generation of soaps detrimental to epoxidized oil separation. ${ }^{152-154}$ Therefore, an easily removable fatty acid with water from epoxidized oils after epoxidation reaction becomes an urgent need to improve the efficiency of this ingrained enzymatic epoxidation method.
Zhang and co-workers ${ }^{48}$ carried out the epoxidation of high oleic soybean oil with or without free fatty acid (oleic acid) and toluene using lipase as a sustainable substitute for the present acid-catalyzed process. It was found that genetically modified high oleic acid soybean oil resulted in epoxidation yields of $95 \%$ at $35{ }^{\circ} \mathrm{C}$ in the absence of FFA and toluene. Another research group used lauric acid as an active oxygen carrier and Novozym 435 from Candida antarctica B as a biocatalyst for the epoxidation of Jatropha curcas seed oil and as a result, great selectivity and elimination of ring-opening reactions are the chief benefits. ${ }^{6}$

With the purpose of using easily removable free fatty acid and to get the final product with a low acid value (AV), the enzymatic epoxidation of sunflower oil was conducted in the presence of Novozym 435 and short-chained butyric acid as an active oxygen carrier. As expected, the system provides the final epoxidized oil with a lower AV of $2.57 \pm 0.11$ and the epoxy oxygen content (EOC) of $6.84 \pm 0.21 \%$ reaching an oxirane conversion of $96.4 \pm 3.0 \%{ }^{46}$ Warwel et al. ${ }^{155}$ produced epoxidized vegetable oils with very high yields and repeated catalyst reusability (up to 15 times).

It was investigated that these immobilized enzymes are more stable and better in catalytic activity. ${ }^{156,157}$ The enzyme cost, its reusability, and its stability are some important factors that determine the overall production cost of the process. ${ }^{158}$ The prominent features of lipase-catalyzed epoxidations that make it more attractive than typical chemical epoxidation are the direct formation of stable peracids from free fatty acids (Scheme 4), mild processing conditions, high conversion, and substantial inhibition of side reactions. ${ }^{159}$ Therefore, they are safer than chemical epoxidation and they meet SHE (safety, health, and environment) standards. ${ }^{160}$

However, lipase catalyzed processes often take long reaction times, ${ }^{121,160,161}$ which can be reduced by the use of sonication. ${ }^{47}$ The hydrogen peroxide to unsaturation ratio, temperature, enzyme loading, stirring speed, reaction time, amount of fatty acid and solvents are the major players in the high conversion and selectivity of the epoxidized product. The optimum conditions of the technological parameters of only some references<smiles>[R]C(=O)OCC(OC([R])=O)[C@H](CO)OC([R])=O</smiles>

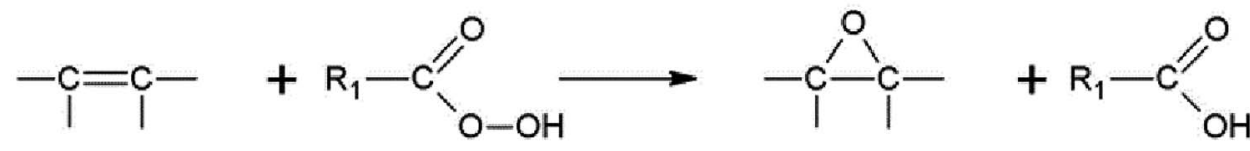

Scheme 5 Chemoenzymatic epoxidation of vegetable oils. ${ }^{150}$ Reprinted from ref. 150. Copyright 1997 Elsevier. 
Table 5 Processing parameters for the epoxidation of vegetable oils using enzymes

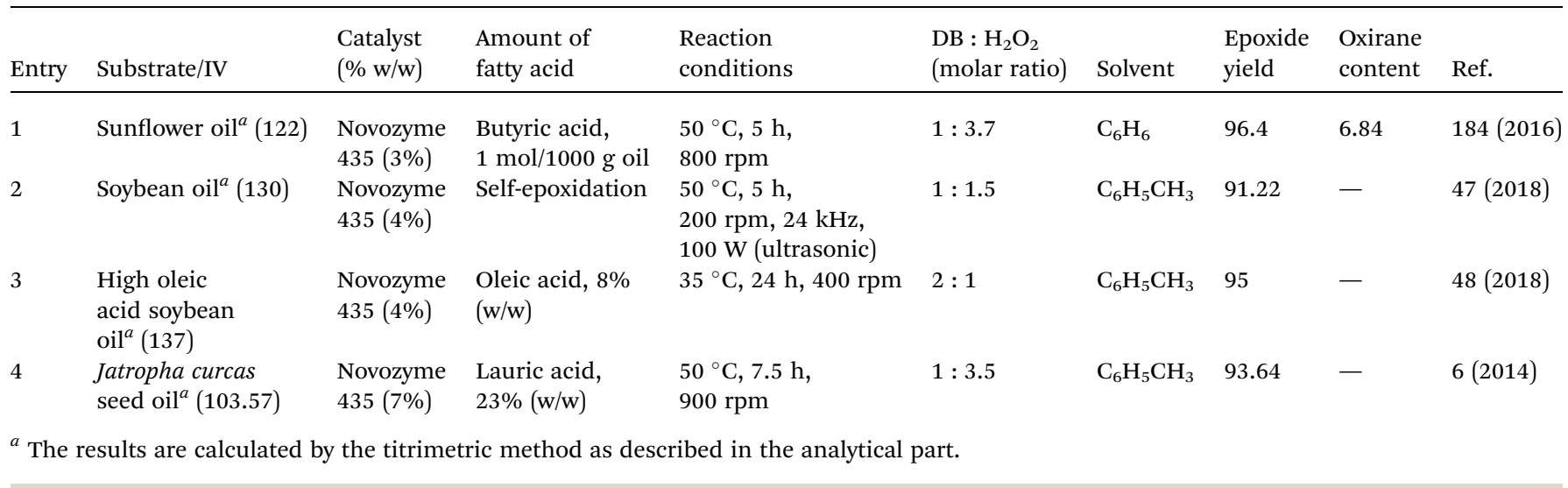

are shown in comparison in Table 5 because Milchert et al. ${ }^{\mathbf{1 0 1}}$ have reviewed in detail about chemoenzymatic epoxidation.

\subsection{Other metal catalyzed heterogeneous system and biobased catalyst}

Turco et al. ${ }^{49}$ used acid zeolites rich in Brønsted acid sites such as the acid exchange resins for selective epoxidation of soybean oil by the in situ generation of peracetic acid inside the pores of the zeolites and epoxidation of bulky triglyceride molecules outside the pores. As a result, a pretreated zeolite with ESBO can get almost complete conversion of the double bonds (96\%) with high selectivity (82\%). Yao et al. ${ }^{50}$ investigated the catalytic activity of silica-supported peroxycarboxylic acid oxidant, 2percarboxyethyl silica $\left(\mathrm{SiO}_{2} @\left(\mathrm{CH}_{2}\right)_{2} \mathrm{COOOH}\right)$ for the epoxidation of olive oil and linseed oil at room temperature, and it was found that this catalyst is promising to give high epoxide yield more than $80 \%$. Somidi and co-workers ${ }^{51}$ prepared sulfated$\mathrm{SnO}_{2}$ catalysts, which can give total conversion of unsaturation of canola oil to epoxidized canola oil with high oxirane content and high lubricity properties. It was observed that niobiumsilica materials with adequate excess of $\mathrm{H}_{2} \mathrm{O}_{2}$ as direct oxidant are suitable for the epoxidation of rapeseed oil because of their good resistance to aqueous reaction media. ${ }^{52}$ It was revealed that CoCuAl layered double hydroxides with different $\mathrm{Co} / \mathrm{Cu}$ atomic ratios prepared by co-precipitation method show moderate conversion in the range of $50-70 \%$ and perfect selectivity of $100 \%$ when they are used for the epoxidation of 12 different oils including edible, non-edible, and waste cooking oil. ${ }^{53}$ Commercial alumina is active in the epoxidation of soybean oil with high oxidant/unsaturation molar ratios and watchful control feeding of hydrogen peroxide to cover the comparable decomposition of hydrogen peroxide. ${ }^{54}$

The immobilization of methyltrioxorhenium(VII) on halloysite nanotubes was conducted by grafting with poly(4-vinyl pyridine) brushes of different lengths and the resultant catalysts were found to be active in the epoxidation of soybean oil with good selectivity. ${ }^{58}$ By using tert-butanol as a diluent, 6\% hydrogen peroxide solution in a polar organic medium, amorphous $\mathrm{Ti} / \mathrm{SiO}_{2}$ catalyst provides high reaction yields and selectivities for the epoxidation of soybean oil. Furthermore, it can suppress undesirable side reactions and $\mathrm{H}_{2} \mathrm{O}_{2}$ decomposition. ${ }^{59} \mathrm{Nb}_{2} \mathrm{O}_{5}-\mathrm{SiO}_{2}$ catalysts synthesized by sol-gel technique have been researched in the epoxidation of soybean oil with hydrogen peroxide. It results in a good activity in the epoxidation reaction because of strong Lewis acid sites but a low selectivity towards epoxide due to strong Brønsted acid sites, which support the epoxide ring opening by hydrolysis. ${ }^{60}$ The detailed parameters and results of all these systems are listed in Table 6 .

\subsection{Intensification of the aforementioned processes in different ways}

In contrast to short chain olefins, VOCs have high viscosity that cause poor mixing due to heat and mass transfer limitations. Besides, the epoxidation reaction is highly exothermic. These factors gave low epoxide yield, unsafe conditions, and unwanted side reactions. Therefore, intensification needs to be done to get high epoxide yield safely and sustainably, and they are trying to meet the target in different alternative ways. As an instance, the intensification of the epoxidation process of soybean oil with performic acid is conducted with the simultaneous addition of all reactants including $\mathrm{H}_{2} \mathrm{O}_{2}$ by highly effective elimination of the exothermic heat to make the process easier and faster in harmless conditions. ${ }^{\mathbf{1 6 2}}$ Songphon Phimsen et al. designed the microreactor coated with $\mathrm{TiO}_{2}$ catalyst and used it for the epoxidation of methyl oleate by using EDTA stabilizer in a solvent free system. Due to the benefits of this reactor, the oxirane oxygen yield is higher up to $43.1 \%$ under the optimum temperature of $60{ }^{\circ} \mathrm{C}$ and residence time of $2.7 \mathrm{~min}$. Contrary to a batch reactor, the reaction time is shortened much from several hours to a couple of minutes in the microcapillary reactor, thus saving energy. However, the stability of $\mathrm{TiO}_{2}$ coated capillary needs to be further developed since the catalyst is peeled off after $3 \mathrm{~h}$ of time on stream (TOS). ${ }^{163}$ Chavan and coworkers ${ }^{62}$ produced epoxidized sunflower oil (ESNO) with $91.1 \%$ conversion to oxirane oxygen by the combined use of ultrasonic bath and mechanical agitation as the equipment intensification. It was concluded that the product can be applied as a safe 


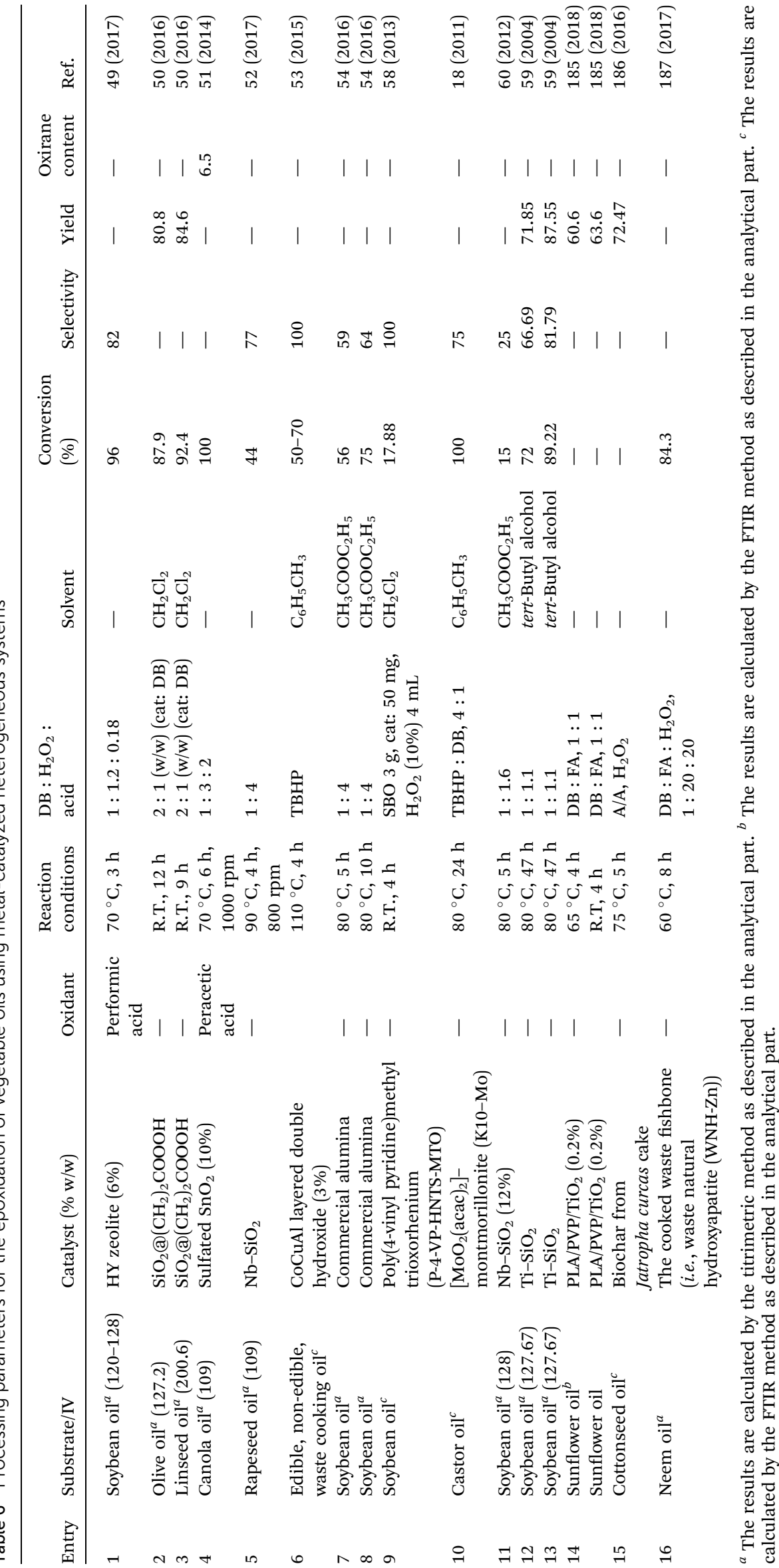


and green secondary plasticizer. It can also be used as a primary one with slightly decreased thermal properties under the optimum parameters such as temperature, pulse of ultrasound, power of ultrasound, concentration of acetic acid, concentration of $\mathrm{H}_{2} \mathrm{O}_{2}$, and catalyst loading. However, the occurrence of very much intense cavitation in the reactor of the ultrasonic horn causes negative effects as higher yields of the unwanted $\alpha$ glycol product. Similarly, in a solvent-free system with a phase transfer catalyst, the synergistic effect of mechanical and ultrasonic agitation results in epoxidized soybean oil with relative percentage conversion to oxirane (90.69\%), the epoxide selectivity (87.48\%), and the epoxide yield (79.34\%) under the optimum conditions. ${ }^{45}$

As the process intensified, epoxidation was tested by an environment friendly route with alternative resources such as waste vegetable oil, citric acid as the only acidic component, and $\mathrm{H}_{2} \mathrm{O}_{2}$ as the green oxidant, thus producing only a liquid residue less noxious than that from the traditional processes. The mechanical and thermal properties of poly(vinyl chloride) (PVC) films using epoxidized waste vegetable oil as a primary plasticizer are similar to those of PVC films in the market. ${ }^{32} \mathrm{~A}$. F. Aguilera et al. focused on a series of studies about microwave technology (MV) in the epoxidation of oleic acid and VOCs in the liquid-liquid system as well as liquid-liquid-solid system by comparing with conventional heating $(\mathrm{CH})$. They revealed that MV heating gave uniform suspension in the aqueousorganic phase, higher yield with $50 \%$ shorter time, and 10 fold lower stirring speed compared to $\mathrm{CH}$. On the other hand, MV is not superior to $\mathrm{CH}$ in the three phase systems using ion exchange catalysts. ${ }^{81-85}$ Aguilera et al. $^{81}$ investigated the synergistic effect of microwave (MW) technology on the epoxidation of cottonseed oil and oleic acid with a special mixing device: a SpinChem Rotating Bed Reactor (RBR) with percarboxylic acid (peracetic acid or perpropionic acid), in the presence of Amberlite IR-120. It was noteworthy that Spinchem RBR supports to overcome the mass-transfer limitations to reduce mechanical friction on the solid catalyst and to reuse the catalyst. However, the effect of Amberlite IR-120 catalyst strongly outpaced the microwave effect.

In two phase systems, MW heating, namely, selective heating causes the temperature gradient between the aqueous and organic phases, which will again enhance the formation of peracid, which is the rate-determining step of epoxidation. With the benefits of microwave irradiation, it gave better reaction yield than the conventional method even in the absence of the catalyst. ${ }^{164}$ However, it should be noted that MV irradiation is not effective in the epoxidation conducted with $70 \mathrm{wt} \%$ of the organic phase. ${ }^{\mathbf{1}}$ It is costlier than $\mathrm{CH}$ in terms of the equipment. ${ }^{87}$

Vianello and co-workers ${ }^{22}$ studied the epoxidation of soybean oil using acetic acid and $34 \mathrm{wt} \%$ hydrogen peroxide rather than the usually used formic acid and $60 \mathrm{wt} \%$ hydrogen peroxide as it is less harmful. In their work, it is interesting that a modified mixing method increases the selectivity from $77 \%$ to $97 \%$ using $500 \mathrm{rpm}$ with intermittently increased speed by $1500 \mathrm{rpm}$ for 30 seconds every 30 minutes throughout the reaction time that is simple but efficient with no cost. Another group analyzed the effect of ultrasonic irradiations on the epoxidation of soybean oil by Candida antarctica (Novozym 435). Consequently, the epoxidized product with the relative percentage conversion to oxirane oxygen of $91.22 \%$ was obtained within $5 \mathrm{~h}$ under mild processing conditions and the lipase was surprisingly stable with six times reusability. ${ }^{47}$ Cortese et al. proposed high temperature simulations, in which the epoxidation of soybean oil was carried out with the addition of all the reactants since the beginning at higher temperatures through the micro-heatexchangers that can manage the release of heat. Consequently, the system gave epoxides with high oxirane number within very short residence time by reducing the tendency of explosion danger through better control. This, in turn, increases the potential productivity at the industrial scale. ${ }^{88} \mathrm{Wu}$ et al. developed a novel reactor that is appropriate for sturdy exothermic heterogeneous reaction systems. Liquid-liquid mixing was intensified by hydrodynamic cavitation, by reducing the droplet size by increased inlet pressure. Advantageously, the temperature increase is only $1{ }^{\circ} \mathrm{C}$ even with single addition of all the reactants. This study can be further extended for the industrial scale epoxidation of VOCs. ${ }^{89}$

\section{Current methods for the analysis of vegetable oils and epoxidized products}

\subsection{Measurement of physicochemical properties}

The knowledge of physicochemical properties is of importance for the optimization of reaction conditions and the scale-up of these processes. For example, viscosity and density are critical properties to establish the mass transfer coefficients. Refractive index could be useful for an online analysis method. Specific heat capacity data are needed for the energy balance of a chemical system. ${ }^{79}$ Abbemat 300 refractometer (Anton Paar, Austria) was used to measure the refractive indexes with an accuracy of $0.0001 \mathrm{nD}$ according to the manufacturer. DMA $4100 \mathrm{M}$ (Anton Paar, Austria) was utilized to determine the densities with an accuracy of measurement of $0.05 \mathrm{~kg} \mathrm{~m}^{-3}$ and accuracy of temperature of $0.02{ }^{\circ} \mathrm{C}$ according to the manufacturer. The dynamic viscosities were investigated by the viscometer Brookfield CAP2000+ (Brookfield Engineering Laboratories, Inc., Stoughton, MA) equipped with a cone plate geometry system and precise temperature control system. CAP spindle 01 was used during the measurement of viscosity.

Specific heat capacity was measured by using a twin C80Setaram calorimeter with the measuring cell filled with the oils ( $c a .1 .0 \pm 0.0001 \mathrm{~g}$ ) and the empty reference cell. The cells were set aside under isothermal conditions at the chosen temperature for $90 \mathrm{~min}$. Then, the temperature was ramped with a rate of $0.5{ }^{\circ} \mathrm{C} \mathrm{min}^{-1}$ to increase the temperature by $2{ }^{\circ} \mathrm{C}$. At that moment, the cells were again kept under isothermal conditions at this new temperature step for $90 \mathrm{~min}$. To determine the $C_{\mathrm{p}}$ values, one needs to consider the energy absorbed by the system, i.e., with no chemicals in the measuring and reference cells. Hence, the values of $C_{\mathrm{p}}$ at a given temperature can be determined using the following equation: 


$$
C_{\mathrm{p}}(T)=\frac{Q_{\mathrm{r}}(T)-Q_{\mathrm{b}}(T)}{m \times \Delta T}
$$

where $Q_{\mathrm{r}}(T)$ is the heat absorbed by the oils at the desired temperature; $Q_{\mathrm{b}}(T)$ is the energy absorbed by the system in absence of oils; $m$ is the mass of oils; and $\Delta T$ is the temperature difference, i.e., $2{ }^{\circ} \mathrm{C} .{ }^{79}$

As functional groups are larger, density is greater. Thus, if the functional group is larger, the difference in density between the vegetable oil and methyl ester is lesser. Thus, both systems have similar densities and density should not be the key parameter describing the difference in reactivity. In contrast to the density behavior, the viscosity difference between vegetable oil and methyl ester derivatives is more prominent. It was found that viscosities of methyl ester and its derivatives could be 20-40 times lower than those of the corresponding vegetable oil and its derivatives. Using vegetable oil instead of fatty acid methyl ester will be a challenge from the mixing point of view. ${ }^{78}$

\subsection{Measurement of conversion, selectivity, and epoxide yield}

In conventional methods, iodine value, epoxy value, and $\alpha$ glycol content are necessary for the determination of conversion, selectivity, and epoxide yield after the epoxidation of vegetable oils. The iodine value of a substance represents the mass of iodine $\left(\mathrm{I}_{2}\right.$, in grams) utilized by $100 \mathrm{~g}$ of that substance and is analyzed to determine the degree of unsaturation (i.e., double bonds) in the fatty acids. ${ }^{165}$ Iodine value is evaluated as per the ASTM D5768 standard as shown in eqn (1), in which double bonds are reacted with Wijs (iodine monochloride) solution leading to the release of $\mathrm{I}_{2}$ that is identified using sodium thiosulfate $\left(\mathrm{Na}_{2} \mathrm{~S}_{2} \mathrm{O}_{3}\right)$.

$$
\mathrm{IV}=\frac{(B-V) \times N \times 12.69}{S}
$$

where: IV refers to the iodine value of the substrate; $B$ refers to the volume of $\mathrm{Na}_{2} \mathrm{~S}_{2} \mathrm{O}_{3}$ needed for blank titration $(\mathrm{mL}) ; V$ refers to the volume of $\mathrm{Na}_{2} \mathrm{~S}_{2} \mathrm{O}_{3}$ required for titration of a sample $(\mathrm{mL})$; $N$ refers to the normality of $\mathrm{Na}_{2} \mathrm{~S}_{2} \mathrm{O}_{3}$ solution $(0.1 \mathrm{~N}) ; S$ refers to the mass of sample used $(\mathrm{g})$.

$\alpha$-Glycol is evolved because of a side reaction called ring opening (cleavage) of the epoxy groups in EVOs during epoxidation. It was determined by the method as described by May et al. ${ }^{109}$ and Stenmark et al., ${ }^{166}$ in which glycol is oxidized via benzylmethyl-ammonium periodate in a nonaqueous solution, whereby excess periodic acid is reacted with potassium iodide (KI) and the liberated $\mathrm{I}_{2}$ is titrated against $\mathrm{Na}_{2} \mathrm{~S}_{2} \mathrm{O}_{3}$. The experimental $\alpha$-glycol content was determined via eqn $(2)^{109}$

$$
\alpha \text {-Glycol content }(\text { moles } / 100 \mathrm{~g})=\frac{(B-S) \times N}{20 \times W}
$$

where: $B$ represents the volume of $\mathrm{Na}_{2} \mathrm{~S}_{2} \mathrm{O}_{3}$ required for titration of blank solution (mL); $S$ represents the volume of $\mathrm{Na}_{2} \mathrm{~S}_{2} \mathrm{O}_{3}$ required for titration of the sample $(\mathrm{mL}) ; N$ represents the normality of $\mathrm{Na}_{2} \mathrm{~S}_{2} \mathrm{O}_{3}$ solution (N); $W$ represents the weight of the sample (oil) used (g).
Several methods have been advanced for the measurement of epoxides in oxidized oils, even though all have different challenges. Among them, the hydrogen bromide ( $\mathrm{HBr}$ ) method has been the most commonly applied method wherein epoxidized VOs are directly titrated with $\mathrm{HBr}$-acetic acid solution (AOCS Method Cd 9-57). ${ }^{167}$ Epoxy content of a sample was measured as per the ASTM D1652-11 standard. EVOs were liquefied in tetra-ethyl ammonium bromide (TEAB/ $\left.\left(\mathrm{C}_{2} \mathrm{H}_{5}\right)_{4} \mathrm{~N}^{+} \mathrm{Br}^{-}\right)$and dichloromethane $\left(\mathrm{CH}_{2} \mathrm{Cl}_{2}\right)$ and titrated with $0.1 \mathrm{~N}$ perchloric acid reagent $\left(\mathrm{HClO}_{4}\right)$. The in situ formation of $\mathrm{HBr}$ results from the reaction between $\mathrm{TEAB}$ and $\mathrm{HClO}_{4}$. $\mathrm{HBr}$ directly reacts with the epoxy group of EVOs, causing the opening of the oxirane ring. Oxirane oxygen can be calculated from eqn (3). ${ }^{168}$

$$
\text { Oxirane oxygen }=\frac{1.6 \times N \times V}{W}
$$

In eqn (3): $V$ refers to the volume of perchloric acid required for titration $(\mathrm{mL}), N$ refers to the normality of perchloric acid $(0.1$ $\mathrm{N})$, and $W$ refers to the mass of EVOs used for titration (g).

However, the method using $\mathrm{HBr}$ is not appropriate for oxidized oils because conjugated dienes, $\alpha$ - and $\beta$-unsaturated carbonyls released during lipid oxidation can also react with $\mathrm{HBr}$, which shows more epoxide content than the real value.

Numerous other methods have been presented recently to estimate epoxides in the substrate, including the use of $\mathrm{N}, \mathrm{N}$ diethyldithiocarbamate (DTC), ${ }^{169} \quad 4$-( $p$-nitrobenzyl)pyridine (NBP), ${ }^{170}$ and transmethylation. ${ }^{171}$ However, these methods are laborious and time-consuming because of the requirement of derivatization of the epoxides before analysis. Usually, the characterization of the epoxidized products using the above analytical procedures takes a long time, requires different chemical, and generates residues. High resolution NMR is a valuable tool for determining the iodine value of vegetable oils as reported by Miyake et al. ${ }^{172}$ In addition, it is a reliable technique to calculate the molecular weight and iodine number of the oil according to Natham and Díaz, ${ }^{173}$ and it has been used for the determination of conversion and selectivity epoxidation for epoxidized VOs. ${ }^{15}$

A rapid attenuated total reflectance Fourier transform infrared (ATR-FTIR) method was used for the determination of oxirane oxygen content (OOC) and changes in the iodine value of VOs. ${ }^{174}$ First, the initial iodine values $\left(\mathrm{IV}_{\mathrm{i}}\right)$ of VOs were obtained from the GC analysis. Second, to draw the FTIR calibration curve, ECO and $\mathrm{CO}$ were subsequently blended in a series of $10 \mathrm{~g}$ samples with different ratios of 0.0 to 1.0 of ECO relative to the sum of the two constituents (ECO/[ECO + CO]) using ECO intervals of $\sim 0.1$. The IV and OOC of these blended mixtures were examined using the standard titrimetric methods and the ATR-FTIR method. The differential spectrum $\left(\Delta_{\mathrm{Abs}}=A_{\mathrm{Blend}}-A_{\mathrm{CO}}\right)$ was obtained by subtracting the spectrum of the CO sample from that of each blended sample. The area of the bands associated with the double bond (H-C-) absorptions (3017.5-3004.2 $\mathrm{cm}^{-1}$ ) as well as that of the oxirane absorptions $\left(1497.3-1432.0 \mathrm{~cm}^{-1}\right)$ were calculated in the resulting differential spectra and plotted against IV and OOC values of the same samples determined by the titrimetric method. A calibration curve was developed by linear regression of areas of IV and OOC from the ATR-FTIR method 
versus the titrimetric results. This calibration enables to convert the FTIR absorption data into IV and OOC values for intermittent samples during the reaction. Both the OOC and $\Delta \mathrm{IV}$ values determined by the ATR-FTIR method correlate well to the values from standard methods $\left(R^{2} \geq 0.992\right.$ and mean relative error of $<3 \%$ ). Thirdly, the conversion, maximum calculated percentage OOC, the yields of epoxides, and the selectivity of the reaction were calculated from the following equations:

$$
\begin{aligned}
\% \text { loss of IV }(\text { conversion })=\left(\text { FTIR } \Delta \mathrm{IV}_{\mathrm{IV}}\right) \times 100 \\
\left.\% \mathrm{OOC}_{\mathrm{i}}\right) \\
\times A_{\mathrm{o}} \times 100
\end{aligned}
$$

where $A_{\mathrm{i}}$ and $A_{\mathrm{o}}$ are the atomic weights of iodine (126.9 $\mathrm{g} \mathrm{mol}^{-1}$ ) and oxygen ( $\left.16.0 \mathrm{~g} \mathrm{~mol}^{-1}\right)$, and $\Delta \mathrm{IV}$ is the measured change in iodine value.

$$
\begin{aligned}
& \begin{aligned}
\% \text { epoxide yield }= & \left(\left(\mathrm{FTIR}_{1497-1432} \mathrm{OOC}\right) /\right. \\
& \left.\% \mathrm{OOC}_{\text {calculated max }}\right) \times 100
\end{aligned} \\
& \% \text { selectivity }=\underset{\left(\left(\mathrm{FTIR}_{1497-1432} \mathrm{OOC}\right) /\right.}{\left.\% \mathrm{OOC}_{\text {calculated max for } \Delta \mathrm{IV})}\right) \times 100}
\end{aligned}
$$

The ATR-FTIR methods described here provide a facile and rapid means of monitoring OOC and IV changes during the epoxidation of vegetable oils.

In ${ }^{1} \mathrm{H}$ nuclear magnetic resonance (NMR), the chemical shifts of epoxide groups were identified and the peak areas were integrated to quantify the epoxides in oils where various internal standards were used. This allowed the monitoring of the reaction and quantification of the result. Moreover, if the substrates are di-unsaturated in the epoxidation reactions, the yields of mono- and di-epoxide can also be calculated. The effectiveness of this method is confirmed by the comparative study of some NMR results with those obtained by GC analysis. ${ }^{35,175-178}$ In one of these investigations, ${ }^{177}$ the non-deuterated chloroform contained in the deuterated chloroform was chosen as an internal reference for quantitative analysis. ${ }^{179}$ Caution must be taken in handling the solvents and the samples when easily evaporated chloroform is used as an internal standard for quantification. In the other study, ${ }^{175}$ signals from methyl groups were referenced as the internal standard for quantification. However, verification is required to use this method for oxidized oils because of alkane formation when lipid oxidation occurs in oils, ${ }^{180}$ particularly at high temperatures. In the absence of water, glycerol protons remained stable during oxidation ${ }^{\mathbf{1 8 1}}$ and hence, became alternative internal standards for ${ }^{1} \mathrm{H}$ NMR quantification.

Farias et $a l .{ }^{15}$ calculated conversion, epoxidation, and selectivity of epoxidized soybean oil with ${ }^{1} \mathrm{H}$ NMR spectrum according to the previous studies ${ }^{\mathbf{1 7 2 , 1 7 5}}$ using the following equations:

$$
\mathrm{ND}_{\mathrm{i}}=\frac{A-\mathrm{NF}}{2 \mathrm{NF}}
$$

$$
\begin{gathered}
\text { Conversion }(\%)=\frac{\mathrm{ND}_{\mathrm{i}}-\mathrm{ND}_{\mathrm{f}}}{\mathrm{ND}_{\mathrm{i}}} \\
\text { Epoxidation }(\%)=\frac{(I+J) / 2}{\mathrm{NF} \times \mathrm{ND}_{\mathrm{i}}} \\
\text { Selectivity }(\%)=\frac{\text { epoxidation }(\%)}{\text { conversion }(\%)}
\end{gathered}
$$

where $\mathrm{ND}_{\mathrm{i}}$ is the number of double bonds in the original oil and $\mathrm{ND}_{\mathrm{f}}$ is the number of double bonds left in EVOs, obtained by substitution into eqn (3) of the corresponding peak areas in the spectrum of the epoxidized oil. $I$ and $J$ are the peak areas related to the hydrogens of the epoxide groups at chemical shifts of 2.9 (mono-epoxide) and 3.1 (di-epoxide) ppm, respectively. NF is the normalization factor (the relative peak area of one hydrogen) obtained from the area of the chemical shift connected with the four hydrogens of the methylene groups of the glycerol moiety. Besides, $A$ is the peak area of the olefinic hydrogens (26.016 g) plus the peak area of methane hydrogen of the glycerol moiety that are all shown in the same region.

\section{Conclusion}

This article reviews various catalytic developments in the preparation and the analysis methods for epoxidized vegetable oils. Since the role of sustainable and biocompatible alternatives to commercial harmful phthalate esters is gaining importance, finding efficient and safe catalysts to obtain epoxidized vegetable oils has become a hot topic for researchers. Several efforts have been made to find the most efficient catalysts for different methods to get high conversion and selectivity after epoxidation, as seen in Tables 2-6. Based on the drawbacks of each system, the process has been intensified to be efficient and environment friendly. Comparing the advantages and disadvantages of different catalytic systems, it is hard to conclude the best one. However, we want to highlight that some metal-catalyzed systems such as $\mathrm{H}-\mathrm{Y}$ zeolite and $\mathrm{SiO}_{2} @\left(\mathrm{CH}_{2}\right)_{2} \mathrm{COOOH}$ are promising catalysts. Keeping in mind the studies and results mentioned in this review, many types of researches should be carried out with a view of finding the perfect heterogeneous catalytic system for the epoxidation of VOs. ATR-FTIR is a useful means to measure conversion, epoxidation, and selectivity but the initial iodine value needs to be measured by GC and calibration curve need to be drawn based on the conventional method and ATR-FTIR. For this reason, with respect to the analysis methods for EVOs, ${ }^{1} \mathrm{H}$ NMR is the most facile and efficient method for both identification and quantitation of the epoxidized VOs in terms of conversion, epoxidation, and selectivity.

\section{Conflicts of interest}

There are no conflicts to declare.

\section{Acknowledgements}

The authors appreciatively acknowledge the financial support from the Fundamental Research Funds for the Central 
Universities (JUSRP51507), the Innovation Foundation in Jiangsu Province of China (BY201423-08), the Postgraduate Innovation Project of Jiangsu Province (KYLX15-1156), and MOE \& SAFEA, 111 Project (B13025).

\section{References}

1 A. Voskian and S. Voskian, Regulation of Plasticizers Under EU REACH and RoHS, available at http:// sysvoskconsulting.com/wp-content/uploads/2016/04/ Regulation-of-Plasticizers-under-EU-REACH-and-RoHSNo.0582-000020.

2 S. G. Tan and W. S. Chow, Polym.-Plast. Technol. Eng., 2010, 49, 1581-1590.

3 Statista, Global production of vegetable oils from 2000/01 to 2018/19 (in million metric tons), available at https:// www.statista.com/statistics/263978/global-vegetable-oilproduction-since-2000-2001/, accessed by June 14, 2019.

4 L. Maisonneuve, T. Lebarbé, E. Grau and H. Cramail, Polym. Chem., 2013, 4, 5472-5517.

5 E. Vanags, M. Kirpluks, U. Cabulis and Z. Walterova, J. Renewable Mater., 2018, 764-771.

6 R. Rafile-Moghaddam, J. Salimon, M. D. J. Haron, H. Jahanngirian, M. H. S. Ismail, S. Hosseini and M. Rezayi, Dig. J Nanomater. Bios., 2014, 9, 1159-1169.

7 A. Carbonell, D. Garcia-Sanoguera, A. Jordá-Vilaplana, L. Sanchez-Nacher and R. Balart, J. Appl. Polym. Sci., 2016, 33, 1-10.

8 X. Meng, G. Chen and Y. Wang, Fuel Process. Technol., 2008, 89, 851-857.

9 D. Salam, N. Naik, M. Suidan and A. Venosa, Environ. Sci. Technol., 2012, 46, 2352-2359.

10 P. Campo-Moreno, Y. Zhao, M. Suidan, A. Venosa and G. Sorial, Chemosphere, 2007, 68, 2054-2062.

11 L. F. Chuah, S. Yusup, A. R. A. Aziz, J. J. Klemeš, A. Bokhari and M. Z. Abdullah, Clean Technol. Environ. Policy, 2016, 18, 473-482.

12 M. M. Gui, K. T. Lee and S. Bhatia, Feasibility of edible oil vs. Non-edible oil vs. Waste edible oil as biodiesel feedstock, 2008.

13 P. Sriromreun, A. Petchsuk, M. Opaprakasit and P. Opaprakasit, Polym. Degrad. Stab., 2013, 98, 169-176.

14 D. E. T. D. H. Wheeler, US Pat., 2,458,484, 1949.

15 M. Farias, M. Martinelli and D. P. Bottega, Appl. Catal., A, 2010, 384, 213-219.

16 B. Rangarajan, A. Havey, E. Grulke and P. Dean Culnan, J. Am. Oil Chem. Soc., 1995, 72, 1161-1169.

17 L. Rios, P. Weckes, H. Schuster and W. Hoelderich, J. Catal., 2005, 232, 19-26.

18 M. Fariasa, M. Martinellib and G. K. Rolimb, Appl. Catal., A, 2011, 403, 119-127.

19 A. B. Kousaalya, S. D. Beyene, V. Gopal, B. Ayalew and S. Pilla, Ind. Crops Prod., 2018, 123, 25-34.

20 J. C. de Haro, I. Izarra, J. F. Rodríguez, Á. Pérez and M. Carmona, J. Cleaner Prod., 2016, 138, 70-76.

21 M. Musik and E. Milchert, Mol. Catal., 2017, 433, 170-174.

22 C. Vianello, D. Piccolo, A. Lorenzetti, E. Salzano and G. Maschio, Ind. Eng. Chem. Res., 2018, 57, 11517-11525.
23 M. Musik, E. Milchert and K. Malarczyk-Matusiak, Pol. J. Chem. Technol., 2018, 20, 53-59.

24 N. Prileschajew, Eur. J. Inorg. Chem., 1909, 42, 4811-4815.

25 J. Wisniak and E. Navarrete, Ind. Eng. Chem. Prod. Res. Dev., 1970, 9, 92-97.

26 J. Wisniak, A. Cancino and J. C. Vega, Ind. Eng. Chem. Prod. Res. Dev., 1964, 3, 306-311.

27 A. Campanella and M. Baltanas, Lat. Am. Appl. Res., 2005, 35, 205-210.

28 A. Campanella and M. Baltanas, Lat. Am. Appl. Res., 2005, 35, 211-216.

29 X. Cai, J. L. Zheng, A. F. Aguilera, L. Vernières-Hassimi, P. Tolvanen, T. Salmi and S. Leveneur, Int. J. Chem. Kinet., 2018, 50, 726-741.

30 A. E. Gerbase, J. R. Gregório, M. Martinelli, M. C. Brasil and A. N. F. Mendes, J. Am. Oil Chem. Soc., 2002, 79, 179-181.

$31 \mathrm{~J}$. Chen, M. de Liedekerke Beaufort, L. Gyurik, J. Dorresteijn, M. Otte and R. J. M. Klein Gebbink, Green Chem., 2019, 21, 2436-2447.

32 A. H. Suzuki, B. G. Botelho, L. S. Oliveira and A. S. Franca, Eur. Polym. J., 2018, 99, 142-149.

33 M. Jankovic, S. Sinadinovic-Fiser, O. Govedarica, J. Pavlicevic and J. Budinski-Simendic, Chem. Ind. Chem. Eng. Q., 2017, 23, 97-111.

34 G. S. Sudha, H. Kalita, S. Mohanty and S. K. Nayak, Int. J. Polym. Anal. Charact., 2017, 22, 519-525.

35 E. Dehonor-Márquez, J. F. Nieto-Alarcón, E. ViguerasSantiago and S. Hernández-Lopéz, Am. J. Chem., 2018, 8, 99-106.

36 R. Mungroo, N. C. Pradhan, V. V. Goud and A. K. Dalai, J. Am. Oil Chem. Soc., 2008, 85, 887-896.

37 O. Gómez-de-Miranda-Jiménez-de-Aberast and J. Perez-Arce, Can. J. Chem. Eng., 2019, 97, 1785-1791.

38 S. Dinda, V. V. Goud, A. V. Patwardhan and N. C. Pradhan, Asia-Pac. J. Chem. Eng., 2011, 6, 870-878.

39 S. Sinadinović-Fišer, M. Janković and Z. S. Petrović, J. Am. Oil Chem. Soc., 2001, 78, 725-731.

40 S. Sinadinović-Fišer, M. Janković and O. Borota, Chem. Eng. Process., 2012, 62, 106-113.

41 R. Turco, R. Vitiello, V. Russo, R. Tesser, E. Santacesaria and M. Di Serio, Green Process. Synth., 2013, 2, 427-434.

42 J. Wu, P. Jiang, X. Qin, Y. Ye and Y. Leng, Bull. Korean Chem. Soc., 2014, 35, 1675-1680.

43 P. Jia, M. Zheng, Y. Ma, G. Feng, H. Xia, L. Hu, M. Zhang and Y. Zhou, J. Cleaner Prod., 2019, 206, 838-849.

44 J. Jiang, Y. Zhang, L. Yan and P. Jiang, Appl. Surf. Sci., 2012, 258, 6637-6642.

45 H. Zhang, H. Yang, H. Guo, J. Yang, L. Xiong, C. Huang, X. Chen, L. Ma and Y. Chen, Appl. Clay Sci., 2014, 90, 175-180.

46 W. Liu, J. Chen, R. Liu and Y. Bi, J. Am. Oil Chem. Soc., 2016, 93, 1479-1486.

47 M. S. Bhalerao, V. M. Kulkarni and A. V. Patwardhan, Ultrason. Sonochem., 2018, 40, 912-920.

48 X. Zhang, J. Burchell and N. S. Mosier, ACS Sustainable Chem. Eng., 2018, 6, 8578-8583. 
49 R. Turco, C. Pischetola, M. Di Serio, R. Vitiello, R. Tesser and E. Santacesaria, Ind. Eng. Chem. Res., 2017, 56, 79307936.

50 M.-Y. Yao, Y.-B. Huang, X. Niu and H. Pan, ACS Sustainable Chem. Eng., 2016, 4, 3840-3849.

51 A. K. R. Somidi, R. V. Sharma and A. K. Dalai, Ind. Eng. Chem. Res., 2014, 53, 18668-18677.

52 S. Dworakowska, C. Tiozzo, M. Niemczyk-Wrzeszcz, P. Michorczyk, N. Ravasio, R. Psaro, D. Bogdał and M. Guidotti, J. Cleaner Prod., 2017, 166, 901-909.

53 S. Sankaranarayanan, A. Sharma and K. Srinivasan, Catal. Sci. Technol., 2015, 5, 1187-1197.

54 R. Turco, C. Pischetola, R. Tesser, S. Andini and M. Di Serio, RSC Adv., 2016, 6, 31647-31652.

55 J. Sepulveda, S. Teixeira and U. Schuchardt, Appl. Catal., A, 2007, 318, 213-217.

56 N. L. Parada Hernandez, A. J. Bonon, J. O. Bahú, M. I. R. Barbosa, M. R. Wolf Maciel and R. M. Filho, J. Mol. Catal. A: Chem., 2017, 426, 550-556.

57 N. Scotti, N. Ravasio, R. Psaro, C. Evangelisti, S. Dworakowska, D. Bogdal and F. Zaccheria, Catal. Commun., 2015, 64, 80-85.

58 J. Jiang, Y. Zhang, D. Cao and P. Jiang, Chem. Eng. J., 2013, 215-216, 222-226.

59 A. Campanella, M. A. Baltanás, M. C. Capel-Sánchez, J. M. Campos-Martín and J. L. G. Fierro, Green Chem., 2004, 6, 330-334.

60 M. Di Serio, R. Turco, P. Pernice, A. Aronne, F. Sannino and E. Santacesaria, Catal. Today, 2012, 192, 112-116.

61 P. Karmalm, T. Hjertberg, A. Jansson and R. Dahl, Polym. Degrad. Stab., 2009, 94, 2275-2281.

62 A. P. Chavan and P. R. Gogate, J. Ind. Eng. Chem., 2015, 21, 842-850.

63 S. Lee, M. S. Park, J. Shin and Y.-W. Kim, Polym. Degrad. Stab., 2018, 147, 1-11.

64 P. G. Nihul, S. T. Mhaske and V. V. Shertukde, Iran. Polym. J., 2014, 23, 599-608.

65 P. Lathi and B. Mattiasson, Appl. Catal., B, 2007, 69, 207212.

66 S. G. Tan and W. S. Chow, Polym.-Plast. Technol. Eng., 2010, 49, 1581-1590.

67 B. Lin and L. Yang, J. Am. Oil Chem. Soc., 2008, 85, 11871188.

68 W. Y. Pérez-Sena, X. Cai, N. Kebir, L. Vernières-Hassimi, C. Serra, T. Salmi and S. Leveneur, Chem. Eng. J., 2018, 346, 271-280.

69 C. Carré, Y. Ecochard, S. Caillol and L. Avérous, ChemSusChem, 2019, 12, 3410-3430.

70 M. Kirpluks, E. Vanags, A. Abolins, A. Fridrihsone and U. Cabulis, J. Cleaner Prod., 2019, 215, 390-398.

71 L. H. Gan, K. S. Ooi, S. H. Goh, L. M. Gan and Y. C. Leong, Eur. Polym. J., 1995, 31, 719-724.

72 J. Chen, X. Li, Y. Wang, J. Huang, K. Li, X. Nie and J. Jiang, Eur. J. Lipid Sci. Technol., 2016, 119, 1-9.

73 S.-W. Kim, J.-G. Kim, J.-I. Choi, I.-R. Jeon and K.-H. Seo, J. Appl. Polym. Sci., 2005, 96, 1347-1356.

74 P. H. Daniels, J. Vinyl Addit. Technol., 2009, 15, 219-223.
75 C. F. Krewson, G. R. Riser and W. E. Scott, J. Am. Oil Chem. Soc., 1966, 43, 377-379.

76 P. Pal, J. Sikder, S. Roy and L. Giorno, Chem. Eng. Process., 2009, 48, 1549-1559.

77 A. Stankiewicz and J. A. Moulijn, Chem. Eng. Prog., 2000, 96, 22-33.

78 X. Cai, M. Matos and S. Leveneur, Ind. Eng. Chem. Res., 2019, 58, 1548-1560.

79 X. Cai, K. A. Aissa, L. Estel and S. Leveneur, J. Chem. Eng. Data, 2018, 63, 1524-1533.

80 L. A. Quinchia, M. A. Delgado, C. Valencia, J. M. Franco and C. Gallegos, Ind. Crops Prod., 2010, 32, 607-612.

81 A. F. Aguilera, P. Tolvanen, S. Heredia, M. G. Muñoz, T. Samson, A. Oger, A. Verove, K. Eränen, S. Leveneur, J.-P. Mikkola and T. Salmi, Ind. Eng. Chem. Res., 2018, 57, 3876-3886.

82 A. F. Aguilera, P. Tolvanen, J. Wärnå, S. Leveneur and T. Salmi, Chem. Eng. J., 2019, 375, 121936.

83 A. F. Aguilera, P. Tolvanen, A. Oger, K. Eränen, S. Leveneur, J.-P. Mikkola and T. Salmi, J. Chem. Technol. Biotechnol., 2019, 94, 3020-3031.

84 A. F. Aguilera, P. Tolvanen, K. Eränen, J. Wärnå, S. Leveneur, T. Marchant and T. Salmi, Chem. Eng. Sci., 2019, 199, 426-438.

85 A. F. Aguilera, P. Tolvanen, K. Eränen, S. Leveneur and T. Salmi, Chem. Eng. Process., 2016, 102, 70-87.

86 S. Leveneur, A. Ledoux, L. Estel, B. Taouk and T. Salmi, Chem. Eng. Res. Des., 2014, 92, 1495-1502.

87 D. Piccolo, C. Vianello, A. Lorenzetti and G. Maschio, Chem. Eng. J., 2018, 1-8, DOI: 10.1016/j.cej.2018.10.050.

88 B. Cortese, M. de Croon and V. Hessel, Ind. Eng. Chem. Res., 2011, 51, 1680-1689.

89 Z. Wu, T. Zheng, L. Wu, H. Lou, Q. Xie, M. Lu, L. Zhang, Y. Nie and J. Ji, Ind. Eng. Chem. Res., 2017, 56, 5231-5238.

90 Y. Leng, J. Wu, P. Jiang and J. Wang, Catal. Sci. Technol., 2014, 4, 1293-1300.

91 J. Zhang, P. Jiang, Y. Shen, W. Zhang and G. Bian, J. Porous Mater., 2016, 23, 431-440.

92 J. Zhang, P. Jiang, Y. Shen, G. Zhao, W. Zhang and B. Gang, Aust. J. Chem., 2016, 69, 817-825.

93 J. Zhang, P. Jiang, Y. Shen, W. Zhang and X. Li, Microporous Mesoporous Mater., 2015, 206, 161-169.

94 B. Gang, P. Jiang, K. Jiang, Y. Shen, L. Kong, L. Hu, Y.-M. Dong and W. Zhang, Aust. J. Chem., 2017, 70, 10391047.

95 G. Bian, P. Jiang, F. Wang, Y. Shen, K. Jiang, L. Liu and W. Zhang, New J. Chem., 2018, 42, 85-90.

96 Y. Shen, P. Jiang, Y. Wang, G. Bian, P. T. Wai and Y. Dong, J. Solid State Chem., 2018, 264, 156-164.

97 Y. Shen, P. Jiang, J. Zhang, B. Gang, P. Zhang, Y.-M. Dong and W. Zhang, Mol. Catal., 2017, 433, 212-223.

98 Y. Shen, P. Jiang, L. Wang, G. Bian, P. T. Wai, P. Zhang and Y. Dong, ChemistrySelect, 2018, 3, 9084-9090.

99 Y. Shen, P. Jian, P. T. Wai, Q. Gu and W. Zhang, Catalysts, 2019, 9, 1-27.

100 E. Milchert, K. Malarczyk-Matusiak and M. Musik, Pol. J. Chem. Technol., 2016, 18, 128-133. 
101 E. Milchert, K. Malarczyk and M. Klos, Molecules, 2015, 20, 21481-21493.

102 S. M. Danov, O. A. Kazantsev, A. L. Esipovich, A. S. Belousov, A. E. Rogozhin and E. A. Kanakov, Catal. Sci. Technol., 2017, 7, 3659-3675.

103 H. Hosney, B. Nadiem, I. Ashour, I. Mustafa and A. ElShibiny, J. Appl. Polym. Sci., 2018, 1-12, DOI: 10.1002/ app.46270.

104 U. Biermann, W. Friedt, S. Lang, W. Lühs, G. Machmüller, J. O. Metzger, M. R. g. Klaas, H. J. Schäfer and M. P. Schneider, Angew. Chem., Int. Ed., 2000, 39, 22062224.

105 R. Chen, PhD thesis, Iowa State University, 2014.

106 S. Guner, Y. Yagci and A. Erciyes, Prog. Polym. Sci., 2006, 31, 633-670.

107 F. Rosillo-Calle, L. Pelkmans and A. Walter, A global overview of vegetable oils, with reference to biodiesel a report to the IEA bioenergy task 40, 2019.

108 S. N. Khot, J. La Scala, E. Can, S. S. Morye, G. I. Williams, G. Palmese, S. Kusefoglu and R. Wool, J. Appl. Polym. Sci., 2001, 82, 703-723.

109 C. May and T. Yoshio, Epoxy Resins: Chemistry and Technology, CRC Press, Boca Raton, 2nd edn, 1973.

110 Statistica, Worldwide oilseed production in 2018/2019, by type (in million metric tons), available via the internet https:/www.statista.com/statistics/267271/worldwideoilseed-production-since-2008/, accessed June 14, 2019.

111 H. Miyagawa, A. Mohanty, M. Misra and L. Drzal, Bio-based epoxy/clay nanocomposites as a new matrix for carbon fiber reinforced composites: thermophysical and medical properties evaluation, 2003.

112 M. Brink and G. Belay, Plant Resources of Tropical Africa 1, PROTA, Leiden, Netherlands, 2006.

113 P.-P. Meyer, N. Techaphattana, S. Manundawee, S. Sangkeaw, W. Junlakan and C. Tongurai, Thammasat Int. J. Sci. Technol., 2008, 13, 13-19.

114 G. Knothe and J. Derksen, Recent Developments in the Synthesis of Fatty Acid Derivatives, J. Am. Oil Chem. Soc., 1999, 90-99.

115 D. Swern, J. Am. Chem. Soc., 1947, 69, 1692-1698.

116 B. M. Abdullah and J. Salimon, J. Appl. Sci., 2010, 10, 15451553.

117 Z. Petrović, A. Zlatanic, C. C. Lava and S. Sinadinović-Fišer, Eur. J. Lipid Sci. Technol., 2002, 104, 293-299.

118 C. Cai, H. Dai, R. Chen, C. Su, X. Xu, S. Zhang and L. Yang, Eur. J. Lipid Sci. Technol., 2008, 110, 341-346.

119 E. Santacesaria, R. Tesser, M. Di Serio, R. Turco, V. Russo and D. Verde, Chem. Eng. J., 2011, 173, 198-209.

120 E. Glukhan, A. Torubarov and M. Stepanski, 2005 AIChE Annual Meeting, 2005.

121 C. Orellana Coca, J. Billakanti, B. Mattiasson and R. HattiKaul, J. Mol. Catal. B: Enzym., 2007, 44, 133-137.

122 E. U. Ikhuoria, R. O. Obuleke and F. E. Okieimen, J. Macromol. Sci., Part A: Pure Appl.Chem., 2007, 44, 235-238.

123 A. E. V. Hagström, U. Törnvall, M. Nordblad, R. Hatti-Kaul and J. M. Woodley, Biotechnol. Prog., 2011, 27, 67-76.
124 M. R. g. Klaas and S. Warwel, Ind. Crops Prod., 1999, 9, 125132.

125 E. Santacesaria, A. Renken, V. Russo, R. Turco, R. Tesser and M. Di Serio, Ind. Eng. Chem. Res., 2012, 51, 8760-8767.

126 S. Leveneur, M. Pinchard, A. Rimbault, M. Safdari Shadloo and T. Meyer, Thermochim. Acta, 2018, 666, 10-17.

127 S. Leveneur, Org. Process Res. Dev., 2017, 21, 543-550.

128 J. L. Zheng, J. Wärnå, T. Salmi, F. Burel, B. Taouk and S. Leveneur, AIChE J., 2016, 62, 726-741.

129 V. Casson Moreno, V. Russo, R. Tesser, M. Di Serio and E. Salzano, Process Saf. Environ. Prot., 2017, 109, 529-537.

130 C. Vianello, E. Salzano and G. Maschio, Process Saf. Environ. Prot., 2018, 116, 718-726.

131 A. Campanella, C. Fontanini and M. Baltanas, Chem. Eng. J., 2008, 144, 466-475.

132 G. Lligadas, J. C. Ronda, M. Galià and V. Cádiz, Biomacromolecules, 2006, 7, 3521-3526.

133 P. L. Lee, W. Yunus, S. Yeong, D. Kuang Abdullah and W. Lim, J. Oil Palm Res., 2009, 21, 675-682.

134 R. Mungroo, N. C. Pradhan, V. Goud and A. Dalai, J. Am. Oil Chem. Soc., 2008, 85, 887-896.

135 K. A. Kun and R. Kunin, J. Polym. Sci., Part C: Polym. Symp., 1967, 16, 1457-1469.

136 B. Corain, M. Zecca and K. Jeřábek, J. Mol. Catal. A: Chem., 2001, 177, 3-20.

137 A. F. Chadwick, D. O. Barlow, A. A. D'Addieco and J. G. Wallace, J. Am. Oil Chem. Soc., 1958, 35, 355-358.

138 A. Campanella and M. A. Baltanás, Eur. J. Lipid Sci. Technol., 2004, 106, 524-530.

139 L. A. Rios, D. A. Echeverri and A. Franco, Appl. Catal., A, 2011, 394, 132-137.

140 S. Leveneur, C. A. de Araujo Filho, L. Estel and T. Salmi, Ind. Eng. Chem. Res., 2012, 51, 189-201.

141 S. Leveneur, D. Y. Murzin, T. Salmi, J.-P. Mikkola, N. Kumar, K. Eränen and L. Estel, Chem. Eng. J., 2009, 147, 323-329.

142 R. Yahya, M. Craven, E. F. Kozhevnikova, A. Steiner, P. Samunual, I. V. Kozhevnikov and D. E. Bergbreiter, Catal. Sci. Technol., 2015, 5, 818-821.

143 J.-M. Brégeault, M. Vennat, S. Laurent, J.-Y. Piquemal, Y. Mahha, E. Briot, P. C. Bakala, A. Atlamsani and R. Thouvenot, J. Mol. Catal. A: Chem., 2006, 250, 177-189.

144 Y. Zhou, Z. Guo, W. Hou, Q. Wang and J. Wang, Catal. Sci. Technol., 2015, 5, 4324-4335.

145 C. Venturello and R. D'Aloisio, J. Org. Chem., 1988, 53, 1553-1557.

146 J. Gao, Y. Chen, B. Han, Z. Feng, C. Li, N. Zhou, S. Gao and Z. Xi, J. Mol. Catal. A: Chem., 2004, 210, 197-204.

147 W. Cheng, G. Liu, X. Wang, X. Liu and L. Jing, Eur. J. Lipid Sci. Technol., 2015, 117, 1185-1191.

148 F. Björkling, S. E. Godtfredsen and O. Kirk, J. Chem. Soc., Chem. Commun., 1990, 1301-1303, DOI: 10.1039/ C39900001301.

149 S. Warwel and M. R. g. Klaas, Lipid Technol., 1997, 45, 1014.

150 M. R. g. Klaas and S. Warwel, J. Mol. Catal. A: Chem., 1997, 117, 311-319. 
151 M. R. g. Klaas and S. Warwel, J. Am. Oil Chem. Soc., 1996, 73, 1453-1457.

152 S. Sun, G. Yang, Y. Bi and H. Liang, J. Am. Oil Chem. Soc., 2011, 88, 1567-1571.

153 H. Lu, S. Sun, Y. Bi, G. Yang, R. Ma and H. Yang, Eur. J. Lipid Sci. Technol., 2010, 112, 1101-1105.

154 S. Sun, X. Ke, L. Cui, G. Yang, Y. Bi, F. Song and X. Xu, Ind. Crops Prod., 2011, 33, 676-682.

155 S. Warwel and M. R. g. Klaas, J. Mol. Catal. B: Enzym., 1995, 1, 29-35.

156 C. Aouf, E. Durand, J. Lecomte, M.-C. Figueroa-Espinoza, E. Dubreucq, H. Fulcrand and P. Villeneuve, Green Chem., 2014, 16, 1740-1754.

157 M. R. g. Klaas and S. Warwel, Ind. Crops Prod., 1999, 9, 125132.

158 U. Törnvall, C. Orellana-Coca, R. Hatti-Kaul and D. Adlercreutz, Enzyme Microb. Technol., 2007, 40, 447-451.

159 D. Méndez-Sánchez, N. Ríos-Lombardía, V. Gotor and V. Gotor-Fernández, Tetrahedron, 2014, 70, 1144-1148.

160 A. S. Bajwa, S. Sathaye, V. M. Kulkarni and A. V. Patwardhan, Asia-Pac. J. Chem. Eng., 2016, 11, 314-322.

161 R. Schneider, L. R. S. Lara, T. Bitencourt, M. da Graça Nascimento and M. R. dos Santos Nunes, J. Braz. Chem. Soc., 2009, 20, 1473-1477.

162 J. V. de Quadros Jr and R. Giudici, Chem. Eng. Process., 2016, 100, 87-93.

163 S. Phimsen, H. Yamada, T. Tagawa, W. Kiatkittipong, K. Kiatkittipong, N. Laosiripojana and S. Assabumrungrat, Chem. Eng. J., 2017, 314, 594-599.

164 T.-C. Chou and J.-Y. Chang, Chem. Eng. Commun., 2007, 41, 253-266.

165 ASTM D5768-02(2018), Standard Test Method for Determination of Iodine Value of Tall Oil Fatty Acids, ASTM International, West Conshohocken, PA, 2018.

166 G. A. Stenmark, Anal. Chem., 1958, 30, 381-383.

167 American Oil Chemists' Society, Official Methods and Recommended Practices of the AOCS, American Oil Chemists' Society Press, Urbana, IL, USA, 6th edn, 2009.

168 Standard Test Method for Epoxy Content of Epoxy Resins, ASTM International (ASTM), 2011 edn, 2012.
169 C. L. Dupard-Julien, B. Kandlakunta and R. Uppu, Determination of epoxides by high-performance liquid chromatography following derivatization with $\mathrm{N}, \mathrm{N}$ diethyldithiocarbamate, 2007.

170 S. C. Agarwal, B. L. Van Duuren and T. J. Kneip, Detection of epoxides with 4-(p-nitrobenzyl) pyridine, 1980.

171 J. Velasco, S. Marmesat Rodas, O. Bordeaux, G. MárquezRuiz and M. Dobarganes, J. Agric. Food Chem., 2004, 52, 4438-4443.

172 Y. Miyake, K. Yokomizo and N. Matsuzaki, J. Am. Oil Chem. Soc., 1998, 75, 15-19.

173 P. Joseph-Natham and E. Díaz-Torres, Introducción a la Resonancia Magnética Nuclear, Limusa, S.A., Mexico, 1980.

174 M. H. Tavassoli-Kafrani, F. R. van de Voort and J. M. Curtis, Eur. J. Lipid Sci. Technol., 2017, 119, 1600354.

175 H. A. J. Aerts and P. A. Jacobs, J. Am. Oil Chem. Soc., 2004, 81, 841-846.

176 W. Xia, S. M. Budge and M. D. Lumsden, J. Agric. Food Chem., 2015, 63, 5780-5786.

177 E. Goicoechea and M. D. Guillen, J. Agric. Food Chem., 2010, 58, 6234-6245.

178 H. A. J. Aerts and P. A. Jacobs, J. Am. Oil Chem. Soc., 2004, 81, 841-846.

179 G. F. Pauli, T. Gödecke, B. U. L. Jaki and D. C. Lankin, J. Nat. Prod., 2012, 75, 834-851.

180 K. M. F. Schaich, Lipid Oxidation: Theoretical Aspects, in Bailey's Industrial Oil and Fat Products, Wiley Online Library, 2005, DOI: 10.1002/047167849X.bio067.

181 M. D. Guillén and P. S. Uriarte, J. Agric. Food Chem., 2009, 57, 7790-7799.

182 T. Desalegn Zeleke, Am. J. Appl. Chem., 2017, 5, 1-6.

183 V. V. Goud, A. V. Patwardhan, S. Dinda and N. C. Pradhan, Eur. J. Lipid Sci. Technol., 2007, 109, 575-584.

184 G. Feng, L. Hu, Y. Ma, P. Jia, Y. Hu, M. Zhang, C. Liu and Y. Zhou, J. Cleaner Prod., 2018, 189, 334-343.

185 B. Nim, P. Sreearunothai, A. Petchsuk and P. Opaprakasit, J. Nanopart. Res., 2018, 20, 1-15.

186 V. F. Silva, L. N. Batista, V. S. Cunha and M. A. S. Costa, Waste Biomass Valorization, 2016, 8, 1265-1271.

187 H. Sahu and K. Mohanty, Can. J. Chem. Eng., 2017, 95, 15261536. 